Review

\title{
Enzyme Inhibitors: The Best Strategy to Tackle Superbug NDM-1 and Its Variants
}

\author{
Xiaoting Li ${ }^{1,2}$, Dongmei Zhao ${ }^{1,2}$, Weina $\mathrm{Li}^{1,2}$, Jichao Sun ${ }^{1,2}$ and Xiuying Zhang ${ }^{1,2, *}$ \\ 1 Heilongjiang Key Laboratory for Animal Disease Control and Pharmaceutical Development, Northeast \\ Agricultural University, Harbin 150036, China; lixting3069@163.com (X.L.); z18103693767@163.com (D.Z.); \\ nb208493@163.com (W.L.); caassjc@163.com (J.S.) \\ 2 Department of Basic Veterinary Science, College of Veterinary Medicine, Northeast Agricultural University, \\ Harbin 150036, China \\ * Correspondence: zhangxiuying@neau.edu.cn
}

Citation: Li, X.; Zhao, D.; Li, W.; Sun, J.; Zhang, X. Enzyme Inhibitors: The Best Strategy to Tackle Superbug NDM-1 and Its Variants. Int. J. Mol. Sci. 2022, 23, 197. https://doi.org/ 10.3390/ijms23010197

Academic Editor: Vicent Moliner

Received: 11 December 2021

Accepted: 23 December 2021

Published: 24 December 2021

Publisher's Note: MDPI stays neutral with regard to jurisdictional claims in published maps and institutional affiliations.

Copyright: (C) 2021 by the authors. Licensee MDPI, Basel, Switzerland. This article is an open access article distributed under the terms and conditions of the Creative Commons Attribution (CC BY) license (https:// creativecommons.org/licenses/by/ $4.0 /)$.

\begin{abstract}
Multidrug bacterial resistance endangers clinically effective antimicrobial therapy and continues to cause major public health problems, which have been upgraded to unprecedented levels in recent years, worldwide. $\beta$-Lactam antibiotics have become an important weapon to fight against pathogen infections due to their broad spectrum. Unfortunately, the emergence of antibiotic resistance genes (ARGs) has severely astricted the application of $\beta$-lactam antibiotics. Of these, New Delhi metallo- $\beta$-lactamase-1 (NDM-1) represents the most disturbing development due to its substrate promiscuity, the appearance of variants, and transferability. Given the clinical correlation of $\beta$-lactam antibiotics and NDM-1-mediated resistance, the discovery, and development of combination drugs, including NDM-1 inhibitors, for NDM-1 bacterial infections, seems particularly attractive and urgent. This review summarizes the research related to the development and optimization of effective NDM-1 inhibitors. The detailed generalization of crystal structure, enzyme activity center and catalytic mechanism, variants and global distribution, mechanism of action of existing inhibitors, and the development of scaffolds provides a reference for finding potential clinically effective NDM-1 inhibitors against drug-resistant bacteria.
\end{abstract}

Keywords: NDM-1; multidrug resistance; variants; enzyme inhibitors; pharmacophore; biological activity

\section{Introduction}

Abusing the use of antibiotics causes the mass production of resistant bacteria and resistance genes. Resistant bacteria and resistance genes can be transmitted to humans via the food chain and environments, which leads to a variety of infectious illnesses, including norovirus and hepatitis A [1-3]. The emergence and spread of multidrug-resistant bacteria (MDR) and antibiotic resistance genes (ARGs) have become an international public health crisis $[4,5]$. A large number of studies have shown that MDR mainly focuses on gramnegative bacteria, especially carbapenem-resistant Enterobacteriaceae (CRE) and carbapenemresistant Acinetobacter baumannii (CRAB) [6,7]. With the increasing awareness of MDR and ARGs in the world, proposing strategies to prevent and control clinical infection is an urgent task. $\beta$-Lactam antibiotics are the most widely used antibacterial agents at present and block bacterial cell walls due to their covalent bond with basic penicillin-binding proteins (PBPs) [8]. Each species of bacteria has its own unique set of PBPs, and each species of bacteria can have 3 to 8 enzymes [9]. However, bacteria have developed sophisticated resistance mechanisms to resist treatments with $\beta$-lactam antibiotics. Among them, $\beta$ lactamases (BLs) represent the most extensive and clinically relevant mechanism $[10,11]$. BLs are expressed by both gram-positive and gram-negative bacteria that hydrolyze the $\beta$-lactam ring, resulting in the inactivation of the drug [12]. 
The Ambler scheme classifies BLs into four classes according to the protein homology of enzymes [13]. Classes A, C, and D are serine $\beta$-lactamases (SBLs) (such as AmpC, KPC, OXA), which can catalyze the hydrolysis of $\beta$-lactam antibiotics by nucleophile serine, and a transient covalent reaction occurs at the active sites [14-16]. Class B BLs, also known as metallo $\beta$-lactamases (MBLs) (such as IMP, VIM, NDM), catalyze the hydrolysis of $\beta$-lactam antibiotics through a non-covalent mechanism and are characterized by one or two equivalents of bound zinc ( $\mathrm{Zn})$ ions that are indispensable for enzyme activity $[17,18]$. MBLs are further divided into three subclasses (B1, B2, and B3), which are mainly defined by differences in the primary zinc coordination layer [19]. New Delhi metallo- $\beta$-lactamase-1 (NDM-1) [20,21] is a new member of the B1 subclass of the MBL superfamily and was first identified in 2008 by Klebsiella pneumoniae (K. pneumoniae) isolated from a Swedish patient [22-24]. Subsequently, NDM-1 has been characterized mainly in Escherichia coli (E. coli), Acinetobacter spp., and (K. pneumoniae) [25,26]. The global appearance of NDM-1 can effectively hydrolyze almost all available $\beta$-lactam antibiotics except for monobactams such as aztreonam, and it spreads quickly between the same species or even different species [27]. Plasmids mediate the blaNDM-1 gene transfer among the same and even different bacterial species, endangering efficacious antibacterial treatments [28,29]. Moreover, NDM-1 positive bacteria have been detected in drinking water and wastewater [30]. Only colistin and tigecycline are effective against NDM-1 producing bacteria, and some NDM-1 producing bacteria are also resistant to these two drugs [31,32]. Ongoing research has suggested that new types of antibiotics will have long research and development periods and high costs. At present, the most effective method against NDM-1 is to design an inhibitor to protect $\beta$-lactam drugs from enzyme hydrolysis. In addition, combining $\beta$-lactam drugs with inhibitors can restore its antibacterial activity and kill pathogenic microorganisms. Although the structural features and information about the mechanism of NDM-1 hydrolysis have been evaluated based on its homologs, it is still a challenge to develop an effective NDM-1 inhibitor for treatment. Of course, only a profound understanding of the structure of NDM-1 and the different mechanisms of action of NDM-1 on different substrate types are helpful for the future drug discovery of NDM-1-producing drug-resistant bacteria to avert catastrophic pandemics.

In this review, the major advances in NDM-1 inhibitor discovery and development were presented. This summary focuses on the effective structural basis and inhibitory mechanism of inhibitors and inhibitors that synergize with $\beta$-lactam antibiotics to restore the drug sensitivity of clinically relevant NDM-1-expressing bacteria in vitro and in vivo.

\section{The Structure of NDM-1}

The NDM-1-encoding gene blaNDM-1 is mostly located on readily transferable plasmids, and NDM-1 consists of 270 amino acids and is expressed at approximately $27.5 \mathrm{kDa}[33,34]$. NDM-1 is a single-chain polypeptide with an N-terminal signal peptide that shuts through the periplasmic space, effectively acts on $\beta$-lactam antibiotics, and inactivates the hydrolysis of antibiotics. The NDM-1 enzyme has a compact spherical structure with a size of $50 \AA \times 40 \AA \times 40 \AA$ and displays a conical $\alpha \beta / \beta \alpha$ sandwich fold. The $\alpha \beta / \beta \alpha$ fold is unique to the MBL superfamily with two central antiparallel $\beta$-sheets flanked by two pairs of $\alpha$-helices. The hydrolysis mechanism of the substrate catalyzed by BLs indicates that the NDM-1 enzyme folded spatial structure is highly adaptable to $\beta$-lactam antibiotics. The right portion (C-terminal) of the NDM-1 molecule consists of two $\alpha$-helices $(\alpha 4$ and $\alpha 5)$ and five antiparallel $\beta$-strands $(\beta 8-\beta 12)$. The left subdomain (N-terminal) consists of two $\alpha$-helices $(\alpha 1$ and $\alpha 2)$ and seven antiparallel $\beta$-strands $(\beta 1-\beta 7)$ (Figure 1) $[12,35,36]$. The $\beta$-chain interacts through hydrophobic groups, the N-terminal $\beta$-chain is highly twisted with a twist angle $>100$ degrees, and $\alpha$-helices and $\beta$-strands are connected by a flexible loop [37]. 


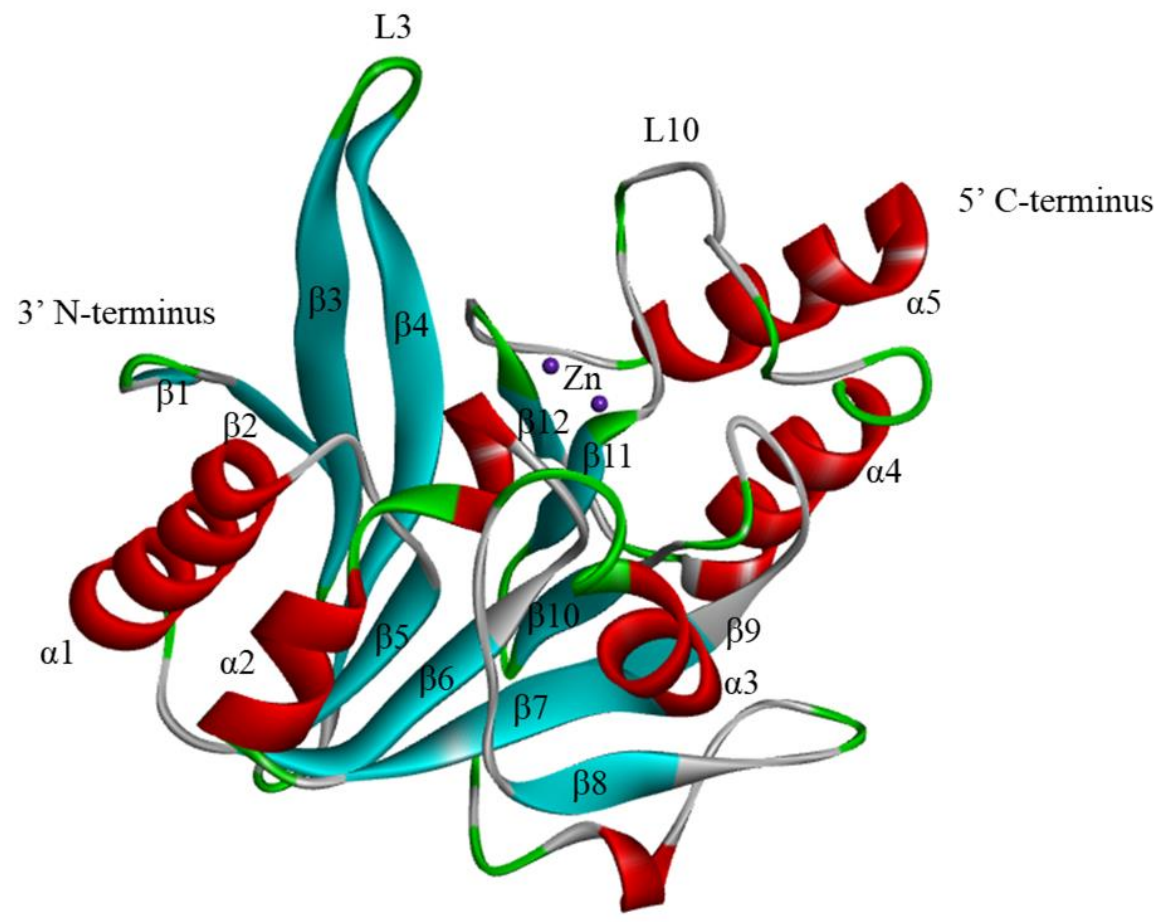

Figure 1. The Crystal Structure of NDM-1 (PDB: 3SPU). The two zinc ions are shown as purple spheres. $\alpha$-Helices and $\beta$-strands are colored red and blue, respectively. The secondary structure designations are labeled.

In solution, the active form of NDM-1 is reported as a monomer, which is similar to other B1 MBLs. In some cases, due to hydrophobic and van der Waals interactions, NDM-1 may exist in the form of a partial dimer, and the loop insertion sequence (Thr162-Gly167) is considered to contribute to the dimerization of NDM-1 [38,39]. It is speculated that NDM-1 can exist as a dimer in both membrane-bound and soluble states, which contributes to the formation of the unique mechanism of resistance of NDM-1 [40].

Many studies are describing the characteristics of NDM-1. To date, many reports of NDM-1 crystal structural determinations have been deposited in the Protein Data Bank (PDB) [41]. These structural models showed that NDM-1 has a typical MBL fold, but a considerable degree of variation exists among the models. These differences include the cocrystallized substrate, the stoichiometry of the bound metal ion, and the conformation of the ligand with substrate binding loops [39]. Dozens of crystal structures of NDM-1 cocrystallized with hydrolyzed antibiotics, including ampicillin (5ZGQ), benzylpenicillin (4EYF), methicillin (4EY2), oxacillin (4EYB), and meropenem (4EYL) (Figure 2) [42,43]. There are also crystal structures of NDM-1 combined with potential inhibitors, such as L-captopril (4EXS) and bisthiazolidine (4U4L). Comparing the root-mean-square deviation (RMSD) values of several different NDM-1 crystal structures, it was found that Loop 3 (residues 63 to 73) contained the greatest flexibility, and the other regions of the protein skeleton were relatively stable $[44,45]$. The crystal structure of NDM-1 cocrystallized with hydrolyzed antibiotics, which reveals the structure-activity relationship (SAR) between the NDM-1 enzyme and its substrate, provides the basis for exploring the mechanism of hydrolyzing antibiotics and broad substrate specificity which further deepens our understanding of these important enzymes. 

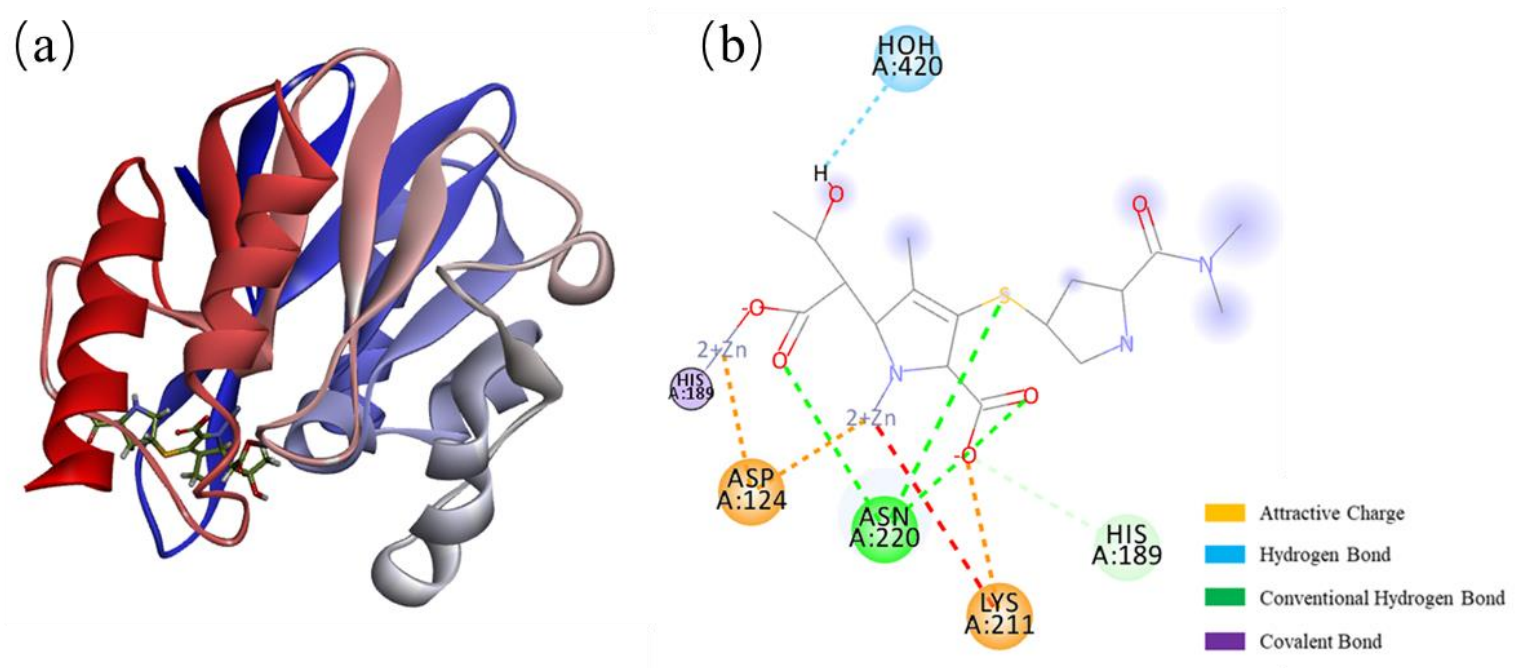

Figure 2. Crystal structure of NDM-1 bound to hydrolyzed meropenem (PDB: 4EYL). (a) Structure of the docking complex of NDM-1 with meropenem. (b) A ligand interaction diagram for NDM-1 and meropenem in the active site.

\section{Active Site and Hydrolysis Mechanism of NDM-1}

In the active site of NDM-1, there are two divalent zinc ions connected by hydroxide ions that interact with different amino acid residues $[46,47]$. $\mathrm{Zn} 1$ is tetrahedrally coordinated with three histidine residues, His120, His122, and His189, with distances of $2.16 \AA, 1.99 \AA$, and $2.19 \AA$, respectively. Zn2 coordinates with Asp124, Cys208, and His250 at distances of $2.42 \AA, 2.52 \AA$, and $2.35 \AA$, respectively [35,42,48] (Figure 3). In addition, Zn2 coordinates with three water molecules, one of which acts as a catalytic water molecule and interacts with $\mathrm{Zn} 1$ and $\mathrm{Zn} 2$. The catalytic water molecule is most likely in the form of hydroxide ions, which form a bridge between the two zinc ions and act as nucleophiles during enzymatic substrate hydrolysis [49-52]. It is assumed that the position of nucleophilic hydroxide is similar to that of all $\beta$-lactam antibiotic product complexes, and it is directly located between Zn 1 and Zn 2, with distances of $2.0 \pm 0.1 \AA$ and $3.0 \pm 0.1 \AA$, respectively [53].

(a)

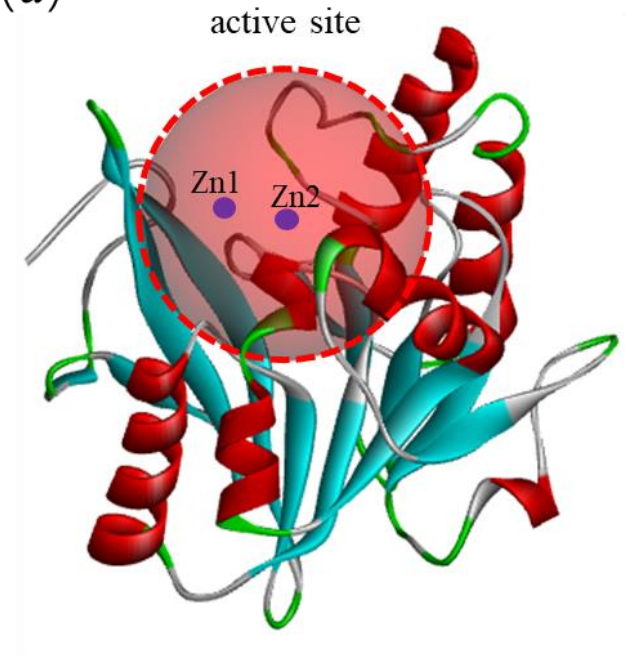

(b)

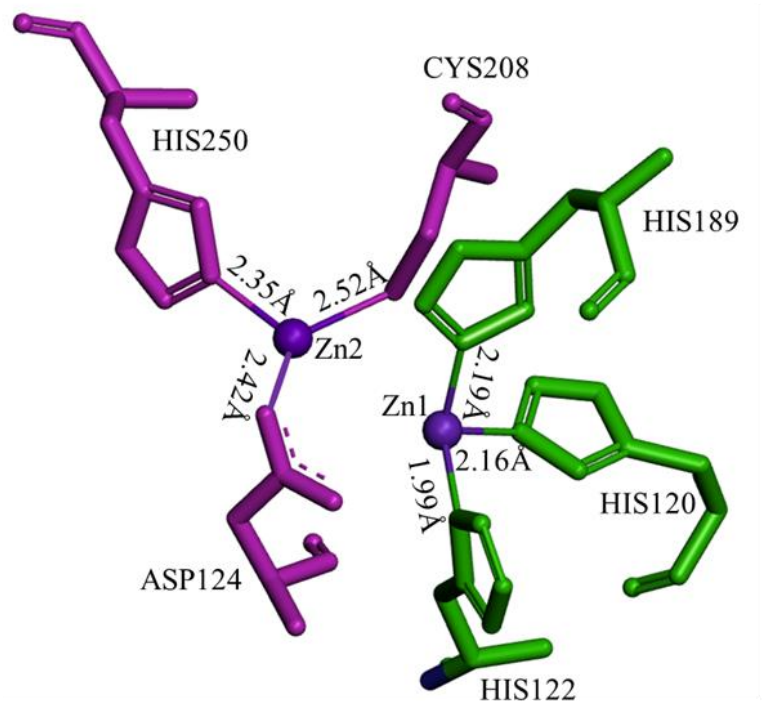

Figure 3. The structure of the NDM-1 active site. (a) The red circle indicates the active site region of NDM-1. (b) Coordination distance between the key amino acids of NDM-1 and zinc. 
In the current proposed NDM-1 enzyme structure model, two zinc ions with a distance of $3.2 \AA$ are connected by the side chain of Asp124 [36,53]. Therefore, $\mathrm{Zn}-\mathrm{Zn}$ ions bind closely during the formation of substrate and enzyme complexes and promote the interaction of $\mathrm{Zn} 2$ with the amide groups of the $\beta$-lactam ring [54]. In addition, the distance of $\mathrm{Zn} 1-\mathrm{Zn} 2$ in the substrate structure increase after hydrolysis, thereby weakening the interaction and releasing the hydrolysate from the NDM-1 enzyme activity center [55]. Zn1 keeps the hydroxyl group in the correct direction to attack the carbon atom on the carbonyl group of the $\beta$-lactam ring by nucleophilicity, while the oxygen atom of the carboxyl group is positioned in a way that enables it to interact with the $\mathrm{Zn} 2$ ion $[56,57]$. The research also shows that the hydroxide ion at the active site attacks the carbonyl carbon of $\beta$-lactam to form an intermediate, and the intermediate is stabilized by zinc ions, thus forming a transition state complex and finally leading to the cleavage of the C-N bond (Figure 4). The catalytic mechanism of NDM-1 is still unclear, and some researchers believe that it follows the dual-zinc catalytic mechanism described above. By only thoroughly understanding the relationship between the active site and the mechanism of hydrolysis, a potential inhibitor may be designed as a future treatment, which is needed in the present situation $[58,59]$.

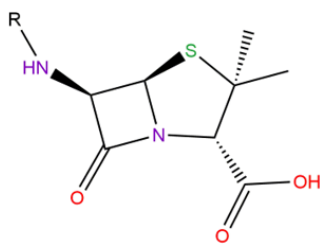

$\beta$-lactam antibiotics

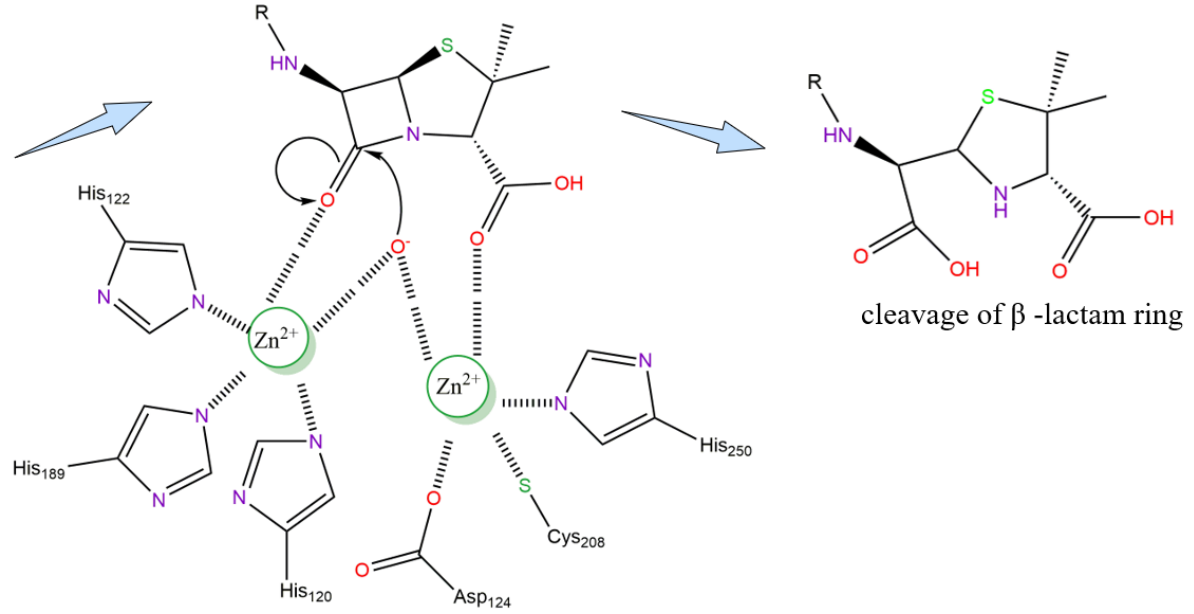

Figure 4. Proposed mechanism hydrolytic mechanism of NDM-1.

\section{NDM-1 Variants and Global Distribution}

The selective pressure caused by the increasing use and abuse of broad-spectrum antibiotics is considered to play a key role in the evolution of NDM-1, leading to the emergence of NDM variants [60,61]. NDM variants are characterized by point mutations at specific positions. To date, substitutions at 21 different positions of the 270 amino acids have been reported, which resulted in 31 different NDM mutations [61-63] (Figure 5). Among 31 known NDM variants, the amino acid substitution pattern is usually between 1 and 5 . NDM-2, -3, -4, -6, -9, -11,-14, -22, -23, -24, -25, -28, -29, -30 and -31 are different from NDM-1 in that they are replaced by a single amino acid, while the rest of them are different due to multiple substitutions. One exception is NDM-18, which is identical to NDM-1, and the only difference is the 5-amino acid tandem repeat sequence (QRFGD) at positions 44-48 of NDM-1 [64]. The secondary structure and thermal stability of the NDM-1 variant were detected by circular dichroism (CD) and differential scanning fluorescence (DSF), and no amino acid mutation was found to affect the whole folding of the NDM-1 variants [65]. However, substitution with different amino acid residues either in various combinations or individually has different effects on the catalytic activity and thermal stabilities of the enzyme in comparison to NDM-1 [66-68]. 


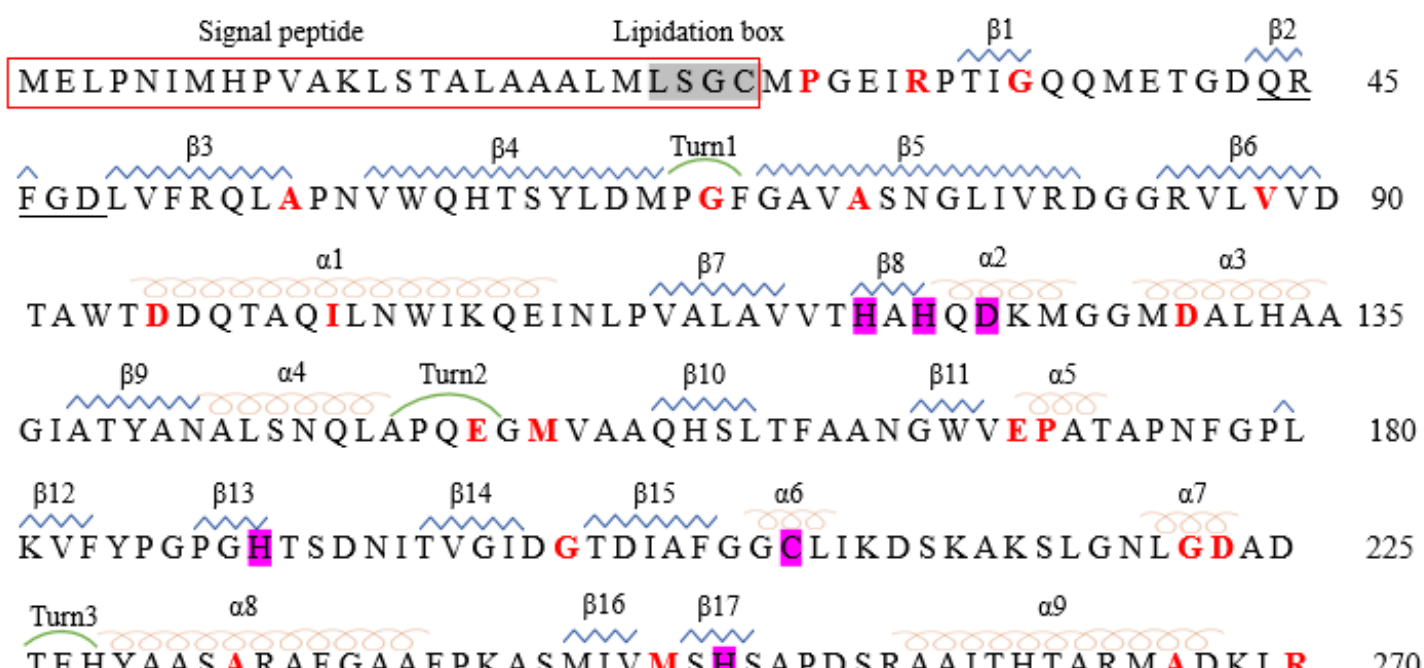

TEHYAASARAF GAAF PKASMIVM S HSAPDSRAAITHTARMA DKL R

Figure 5. NDM-1 amino acid sequence and NDM-1 point mutations. The annotation of the NDM amino acid sequence was adopted from data reported under UniPort. Signal peptides of NDM-1 are framed with red lines. $\alpha$-helices, $\beta$-strands, and turns are indicated as orange spirals and blue zigzag lines and green apsidal lines, respectively. The zinc-binding residues are highlighted in purple. The lipidation box is highlighted in gray.

In the process of NDM evolution under the selection of environmental pressure, residue M154 appears to be the most frequently replaced, among which the mutation of M154L is the most common change (observed in 14 of the 31 distinct NDM variants) and M154V occurred once (in NDM-11). The mutation M154L, which appears on the surface of the protein together with other mutations, is regarded as one of the most favorable substitutions, as it enhances the metal-binding affinity and may improve thermostability through other mechanisms, such as eliminating a charge in one of two closely situated aspartate residues (D130N and D95N) or reducing the flexibility of the loop (G222D) [61,69,70]. Several mutations may introduce other mutations as global suppressors to stabilize the hydrophobic core of NDM, especially M154L, which leads to additional function at the cost of structural instability [71]. Global-suppressing mutations have been researched in the evolution of SBLs [72].

To date, it has been observed that amino acid substitutions in NDM variants are far from the key catalytic residues or those residues related to maintaining active site conformation or substrate interaction. However, some variants have been reported to change the activities against $\beta$-lactam [73], which suggests that a substitution, despite being located at a nonactive site, may distort the groove, resulting in a major impact on enzyme activity, and the mechanism of the increase in activity remains unclear [74]. Observing the distribution of all substitutions in the crystal structure of NDM-1 mutants, it was found that the loop regions were the most susceptible to mutations. More than half of the substitutions are located within the loops of the NDM structure, followed by the $\alpha$-helices and then in the $\beta$-strands (Table 1). The loop region is also mainly involved in mediating drug resistance, which indicates that substitutions in the loops may provide an evolutionary advantage for bacteria $[75,76]$. 
Table 1. Corresponding amino acid substitutions among NDM-1 and its variants and its first source of spread.

\begin{tabular}{ccccc}
\hline \multirow{2}{*}{ NDM-1 } & \multicolumn{2}{c}{ Location of Amino Acid(s) Substitution } & Source \\
\cline { 2 - 5 } Variant & A-Helices & $\beta$-Strands & Loop & Organism(s) \\
\hline NDM-2 & - & - & P28A & A. baumannii \\
NDM-3 & D95N & - & - & E. coli \\
NDM-4 & - & - & M154L & E. coli \\
NDM-5 & - & V88L & M154L & E. coli \\
NDM-6 & A233V & - & - & E. coli \\
NDM-7 & D130N & - & M154L & E. coli \\
NDM-8 & D130G & - & M154L & E. coli \\
NDM-9 & - & - & E152K & K. pneumoniae \\
NDM-10 & - & A74T & R32S, G36D, G69S, G200R & K. pneumoniae \\
NDM-11 & - & - & M154V & E. coli \\
NDM-12 & G222D & - & M154L & E. coli \\
NDM-13 & D95N & - & M154L & E. coli \\
NDM-14 & D130G & - & - & A. lwoffii \\
NDM-15 & A233V & - & M154L & E. coli \\
NDM-16 & A233V & V88L & M154L & E. coli \\
NDM-17 & - & V88L & M154L, E170K & E. coli \\
NDM-18 & - & - & QRFGD (44-48) & P. rettgeri \\
NDM-19 & D130N & - & M154L, A233V & E. coli \\
NDM-20 & - & V88L & M154L, R270H & E. coli \\
NDM-21 & - & V88L & G69S, M154L & E. coli \\
NDM-22 & - & - & M248L & E. cloacae \\
NDM-23 & I101L & - & - & K. pneumoniae \\
NDM-24 & - & V88L & - & P. stuartii \\
NDM-25 & - & A55S & - & K. pneumoniae \\
NDM-26 & G222S & V88L & - & M154L coli \\
NDM-27 & D95N, A233V & - & - & E. coli \\
NDM-28 & A266V & - & - & K. pneumoniae \\
NDM-29 & D130N & - & - pneumoniae \\
NDM-30 & D223Y & - & K. oxytoca \\
NDM-31 & P171T & - & C. werkmanii \\
\hline
\end{tabular}

It is speculated that various amino acid substitutions affect the stability and catalytic activity of the enzyme. NDM variants containing the V88L substitution of NDM-5, -16, $-17,-21$, and -24 have been reported to show higher carbapenem activity than that of NDM-1, while NDM-20 decreased the activity of carbapenems. The minimal inhibitory concentration (MIC) of ertapenem against strains producing NDM-5 -16 and -24 is 4- to 8 -fold higher than that of strains producing NDM-1, while strains producing NDM-21 have carbapenem similar to that of NDM-5 [77-81]. Compared with NDM-5 (V88L and M154L), NDM-20 (V88L, M154L, and R270H) improves the hydrolysis activity of some penicillins and cephalosporins but inhibits the activity of carbapenems, which may influence drug strategies in CRE infection [82]. Experimental studies have shown that the affinity of NDM-17 (V88L, M154L, and E170K) for all $\beta$-lactams is significantly higher than that of NDM-5 (V88L and M154L), and the increase in its catalytic activity may be related to the novel substitution of E170K. Other substitutions of NDM-4 (M154L) and NDM-14 (D130G) have also been found to increase carbapenem activity $[83,84]$. However, NDM-8 contains both M154L and D130G substitutions, but enzymatic activities against carbapenems were similar to those of NDM-1 [85]. Regarding NDM-7 (D130N and M154L), in which the Asp at position 130 replaces Asn in NDM-8, it has been reported that the carbapenem activity of NDM-7 is higher than that of NDM-1 [86]. This indicates that the substitution of different amino acid residues on the same site will have different effects on the catalytic activity of the enzyme, which depends on the structure and properties of different amino acids. Above all, these results explained that different combinations of amino acid mutations have different effects on the catalytic activity of NDM-1. In the single substitution variants, 
it is easy to associate the substitution with an increase or decrease in catalytic activity. However, it is difficult to accurately predict the individual contribution of each substitution in multiple substitution variants. Further comparative kinetic studies can provide insight into the effects of individual substitutes $[76,87,88]$.

NDM variants increase their stability or Zn binding affinity through the accumulation of mutations, while $\mathrm{Zn}$ deprivation strictly limits the evolution of this MBL [69]. Under conditions of zinc starvation, NDM-3 (D95N), -4 (M154L), -6 (A233V), -9 (E152k), and -14 (D130G) variants enhance cefotaxime resistance by increasing the metal affinity or stability of NDM enzymes, but the mechanism is still unclear. In contrast, NDM-2(P28A) and NDM -11(M154V) had no significant influence on NDM function under zinc-restricting conditions. NDM-19 (D130N, M154L, and A233V) is a derivative of NDM-7 (D130N and M154L). Under zinc-restricted growth conditions, compared to NDM-1 or NDM-7, NDM-19 shown is less sensitive to carbapenems and cephalosporins [89]. Therefore, the stress caused by zinc depletion may be the major driving force for the evolution of NDM enzymes [61,69]. To date, there has been no research report on new variants of NDM-28, -29, -30, and -31 enzyme activities. Therefore, it is essential to analyze the catalytic efficiency and resistance of evolving NDM variants in the control of clinical infections, which is still an important task.

According to reports, NDM-1 and its variants are spreading worldwide [21,90,91]. The Asian continent is the main storage area for NDM producers, where approximately $58.15 \%$ of the abundance of NDM- 1 and its variants are distributed, especially in China, Bangladesh, and India [92-94]. NDM-2 was the first variant of NDM-1, which spread NDM carbapenemases in A. baumannii, and the corresponding gene mainly spread in the Middle East [95]. However, NDM-1 and its variant total producers in European countries were approximately $16.8 \%$, Romania, Germany, London, etc. with the maximum spread of NDM-1 variant $[94,96,97]$. NDM-4, -5 , and-7 are reported to be prevalent in European subcontinent countries in Italy, Denmark, and France [94,98]. Africa and the American continent account for approximately $10.8 \%$ of the global NDM-1-producing countries, of which the Algeria subcontinent and Brazil are the main distribution areas, and NDM-5 is also reported to be distributed in Algeria [99]. Australia accounts for 1.6\% of the total NDM-1 producers in the world [100]. All 31 NDM variants detected the highest prevalence in E. coli and K. pneumoniae species.

\section{NDM-1 Inhibitors: Discovery and Advances}

Although a variety of mechanism-based inhibitors are available for SBLs in therapy, there is still a lack of specific and effective inhibitors against NDM-1 in clinical practice [101-103]. The development of effective inhibitors of NDM- 1 is impaired by factors such as variability in the entry loop permutation of the active site, the lack of new scaffolds that can selectively target the active site of NDM-1, and the existence of multiple variants of NDM-1 [104-106].

The widespread emergence of NDM- 1 and its variants has promoted research on antibacterial drugs worldwide. The design and research strategies of drugs targeting NDM-1 have focused on two approaches. First, NDM- 1 is combined with carbapenem antibiotics (such as imipenem), which can not only protect the structure of $\beta$-lactam antibiotics from being destroyed but also synergize with carbapenem drugs to restore their curative effect on NDM-1. Theoretically, these inhibitors should be $\beta$-lactam antibiotics [107]. The second is to design new antibiotics that are insensitive to the catalytic hydrolysis of NDM-1. There is still much progress necessary for new antibiotics that require more effort to innovate and must be explored from scratch. Therefore, most efforts have focused on the first approach, as it offers the ability to protect $\beta$-lactam antibiotics from hydrolysis when they are used in combination with inhibitors [108]. Due to the high structural similarity between the MBL subtypes, it is assumed that these inhibitors play a broad role in the MBLs [103].

To date, more than 500 small-molecule compounds have been reported in the literature as potential NDM-1 inhibitors, but there are no clinically approved NDM-1 inhibitors [27]. In this paper, the active chemical scaffolds of NDM-1 inhibitors that have been discovered 
are reviewed to summarize the pharmacophore and lay a foundation for the subsequent development of NDM-1 inhibitors. NDM-1 inhibitors can be classified and separated into noncovalent inhibitors and covalent inhibitors according to different modes of action.

\subsection{Noncovalently-Bound Inhibitors}

Noncovalent inhibitors mainly consist of zinc-binding inhibitors, boronic acid derivatives, and metal chelating inhibitors.

\subsubsection{Zinc-Binding Inhibitors}

The reaction mechanism of NDM-1 was investigated through the formation of heterobimetallic analogs ( $\mathrm{CoCo}-, \mathrm{ZnCo}-$, and $\mathrm{CoCd}-)$ and the use of chromatic as a chromogenic substrate. The results show that the zinc ion of NDM-1 is essential in the hydrolysis of $\beta$-lactam antibiotics [56]. The electrophilic zinc ions in the NDM-1 enzyme and the electron-rich substituent of NDM-1 inhibitor act synergistically to produce inhibitory activity through ion-dipole interactions.

\section{Thiol-Based Derivatives}

L-captopril (1, Figure 6) is the first angiotensin-converting enzyme (ACE) inhibitor to be clinically approved for the treatment of hypertension [109]. Like ACE, MBLs also contains two key zinc atoms in the active site, so it is no surprise that both enantiomers of captopril are studied as potential NDM-1 inhibitors [110]. D-Captopril (2, Figure 6) has a high inhibitory effect on NDM-1, with a half-maximal inhibitory concentration (IC50) of $7.9 \mu \mathrm{M}$, while the inhibitory activity of L-captopril is 25 -fold less potent, with an IC50 of $202.0 \mu \mathrm{M}$ [36]. The crystal structure of NDM-1 combined with L-captopril was obtained by mass spectrometry and X-ray crystallography. The crystal structure showed that the thiol unit of L-captopril was intercalated between $\mathrm{Zn} 1$ and $\mathrm{Zn} 2$ in the active site of NDM1 , replacing water molecules and becoming a competitive inhibitor of NDM-1 [42]. In addition, Asn220 is a residue involved in intermediate product stabilization and substrate binding. It forms a hydrogen bond with the hydrophilic part of the inhibitor, while the hydrophobic part of the inhibitor interacts with the L3 loop.

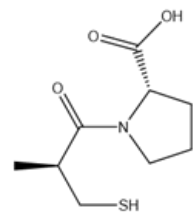

1 L-captopril<smiles>CC(C)(S)[C@H](N)C(=O)O</smiles>

6 Penicillamine

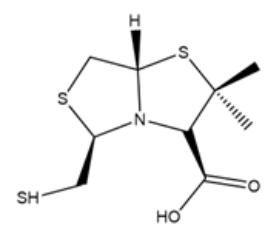

$11 \mathrm{~L}-\mathrm{VC} 26$

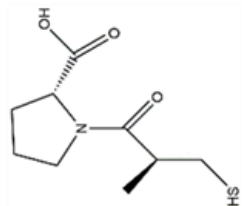

2 D-captopril<smiles>O=C(O)C(S)c1ccccc1</smiles>

7 Thiomandelic acid<smiles>SCc1ccccc1</smiles>

12 Benzyl thiol

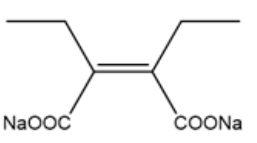

3 ME1071<smiles>O=C(O)CNC(=O)C(CS)Cc1ccccc1</smiles>

4 Thiorphan<smiles>O=C(O)C(S)Cc1ccccc1</smiles>

8 2-mercapto-3-phenyl propionic acid<smiles>O=C(O)c1ccc(-c2ccccc2)cc1CS</smiles>

13 Benzyl thiol<smiles>CC(S)C(=O)NCC(=O)O</smiles>

9 Tiopronin<smiles>OCC(S)CS</smiles>

5 Dimercaprol

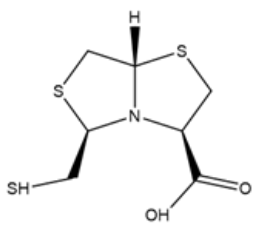

10 L-CS319
Figure 6. Structures of NDM-1 inhibitors containing thiol groups. 
Captopril contains thiol and carboxylate pharmacophores, which can form coordination bonds with $\mathrm{Zn}$ ions. These chemical groups are the reasons why L- and D-captopril have strong inhibitory effects on all subclasses of MBLs, and these effects have been verified for a long time [111-113]. When the carboxylate group of mercaptocarboxylic acids was substituted by bioisosteric groups such as phosphonic acids, the biological activity, and inhibitor binding were reduced, which further demonstrated the importance of the carboxylate acid group [114]. The maleic acid derivative disodium 2,3-diethylmaleate (ME1071, 3 Figure 6) containing carboxylate showed that the activity of carbapenems and cephalosporins on clinical isolates producing MBL was enhanced in vitro [108]. In vivo, the combined application of ME1071 and biapenem can improve the survival rate of ventilator-associated pneumonia in a mouse model caused by MBL-producing Pseudomonas aeruginosa [115].

Captopril has been identified as an effective inhibitor of NDM-1, which is the starting point for the development of new inhibitors with thiol and carboxyl pharmacophores. Captopril consists of two units: a 3-mercapto-2-methylpropanoyl fragment and a proline residue. To test various D-captopril analogs produced by substituting proline residues or partially modifying 3-mercapto-2-methylpropanoyl, Klingler and coworkers created a promising platform for screening and developing new MBL inhibitors [116]. This approach has succeeded in finding three FDA-approved drugs possessing a sulfhydryl moiety with a low $\mu$ M IC 50 range for MBLs. Thiorphan (4, Figure 6), an enkephalin inhibitor, showed high inhibitory activity against NDM-1 with an IC50 of $1.8 \mu \mathrm{M}$. Dimercaprol (5, Figure 6) is clinically used as an antidote for metal poisoning and has the lowest IC50 $(1.3 \mu \mathrm{M})$, and is the most potent. Penicillamine (6, Figure 6) is a drug for Wilson's disease that also shows NDM-1 enzyme inhibitory activity. Among the thiol-based compounds, thiomandelic acid (7, Figure 6) and 2-mercapto-3-phenyl propionic acid (8, Figure 6) were found to efficiently restore sensitivity to meropenem [117]. The above analogs can restore the imipenem susceptibility of E. coli carrying such MBLs. In contrast, tiopronin (9, Figure 6), with an IC50 of $84 \mu \mathrm{M}$, has only moderate activity, while N-acetylcysteine has no activity at all [116].

González and coworkers designed and synthesized a novel chemical scaffold bisthiazolidine (BZTS), derivative according to the mechanism of NDM-1 identifying and hydrolyzing $\beta$-lactam antibiotics. The BTZ scaffold is a structure with the characteristics of a $\beta$-lactam substrate and can be modified by introducing metal-binding groups to target the MBL active site. The modification ability is based on the BTZs bicyclic ring, which could simulate the unbreakable $\beta$-lactam ring, retain the bridging nitrogen and the carboxylate that interact with $\mathrm{Zn} 2$, and accommodate other metal-binding groups inserted into the necessary Zn center. Four BTZs derivates (L-CS319, L-VC26, and their enantiomers, 10, 11, Figure 6) that behave as competitive NDM-1 inhibitors in vitro, with Ki values in the low micromolar range from 7 to $19 \mu \mathrm{M}$, and could restore the efficacy of carbapenem on clinical isolates that produced NDM-1. The two key pharmacophores of the four BTZ derivatives are carboxylate, which interacts with Lys224, and the thiol group and binds to the two Zn ions in the active site of NDM-1 [45]. Therefore, Lys224 was demonstrated to participate in the substrate to identify and adjust substrates toward easy hydrolysis [35,38]. The crystal structure of the most effective L-CS319 and NDM-1 complex (PDB 4u4l) has been clarified, which provides a reference for structural determinants for inhibitor binding and further improves its efficiency [45]. Although compared with NDM-1, other MBL subclasses have different binding modes with BTZs, BTZ scaffolds have also been confirmed to have a broad spectrum of inhibiting all MBL subclasses [118]. This is an effective new strategy to inhibit NDM-1 and provides a valuable scaffold for discovering NDM-1 inhibitors in the future.

In molecular design based on silicon fragments, Cain $\mathrm{R}$ and colleagues reported thiol-mediated potent MBL inhibitors [119]. Utilizing a molecular fragment docking approach, benzyl thiol (12, Figure 6) was discovered as a potential competitive inhibitor of NDM-1 with a low micromolar affinity. Docking calculations and polarizable molecular mechanics predicted interactions between the benzyl thiol derivative (13, Figure 6) and 
NDM-1 [120,121]. The carboxylate forms hydrogen bond interactions with Lys224 and $\mathrm{Zn} 2$, the thiol coordinated $\mathrm{Zn} 1$ and $\mathrm{Zn} 2$, and the aryl ring interact with Trp87 through $\pi$-stacking. Nuclear magnetic resonance (NMR) and crystallographic analyses showed that benzyl thiol derivatives were directly combined with MBL active sites. SAR studies have shown that the terminal phenyl ring of derivative modification with heterocycles or substituents revealed has no significant influence on the effectiveness of the designed inhibitor. Within the detection range, none of the individually tested derivatives had any antibacterial activity, but at an active ingredient concentration of $100 \mu \mathrm{g} / \mathrm{mL}$, the MIC of meropenem to NDM-1-producing strains was decreased. This design can effectively identify the chemotypes of other inhibitors that involve substitution of metal coordination, as well as inhibitors that are dependent on metal coordination.

More recently, 2-mercaptomethyl thiazolidines (MMTZs, 14, Figure 6) were demonstrated to be all MBL inhibitors; they contain a thiazolidine ring and two chiral carbon centers with free thiol groups and carboxylates. MMTZs inhibit MBLs, including NDM-1, by maintaining a conserved binding mode, which utilizes thiol-coordinated mono- or dizinc centers, and thiazolidine sulfur interact with aromatic residue $\mathrm{f}$ active site. In vitro, MMTZs inhibit all MBL subclasses with Ki values ranging from $0.16 \mu \mathrm{M}$ to $130 \mu \mathrm{M}$ and can restore the activity of carbapenems against NDM-1-expressing recombinant E. coli. Therefore, MMTZs represent a promising MBL inhibitor scaffold to control the emergence of bacterial resistance [122].

\section{Rhodanine}

Rhodanine (15, Figure 7) is one of the few compounds with inhibitory activity in all enzyme classes. Due to the noncompetitive or competitive inhibition of PBPs, some rhodanines also have antibacterial activity $[123,124]$. Later, Brem et al., through crystallographic analyses of the mechanism by which rhodanine inhibits VIM-2 MBL, revealed that the rhodanine ring was hydrolyzed into thioenolate (16, Figure 7), and thioenolate was bound by dizinc chelation. Crystallographic observations and NMR analyses in solution revealed that the thioenolate derived from rhodanine as an efficient broad-spectrum MBL inhibitor [125]. Synthesis and characterization of 26 rhodanine derivatives and 1 thioenolate derivative to develop broad-spectrum MBL inhibitors. The biochemical evaluation revealed that most of the tested derivatives strongly inhibited B3 MBL. In particular, for NDM-1, compound 17 (17, Figure 7) was the most active. SAR and Dock showed that the substitution of rhodanine with diaryl provides a good scaffold for the design of broad-spectrum inhibitors of $\mathrm{M} \beta \mathrm{Ls}$ [126].

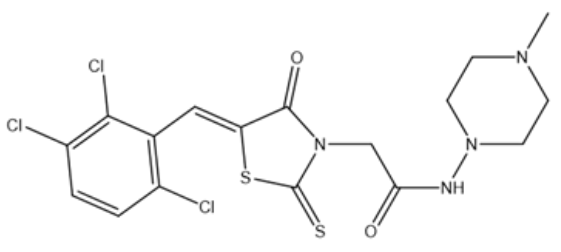

15 Rhodanine

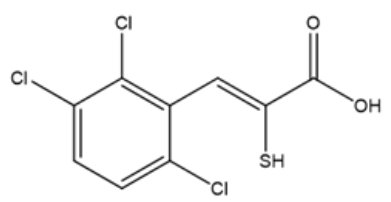

16 Thioenolate

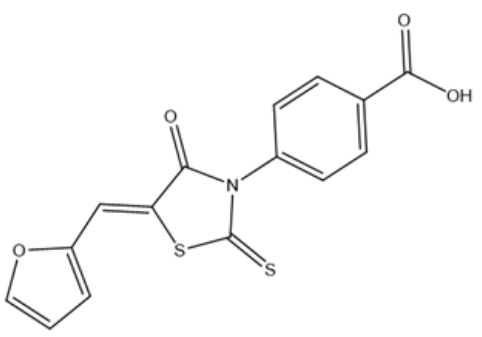

17

Figure 7. Rhodanine derivatives as NDM-1 inhibitors.

Thiadiazoles

A high-throughput screening method was established by Falconer B and coworkers to discover the chemical perturbants of the essential. Therefore, two spiro-indolinethiadiazoles (5-ethyl-5' -phenyl-3'H-spiro[indoline-3,2'-[1,3,4] thiadiazol]-2 and 5-bromo-1methyl-5'-phenyl-3'H-spiro[indoline-3,2'-[1,3,4] thiadiazol]-2) $(18,19$, Figure 8$)$ that disrupt 
iron homeostasis in bacteria have been identified and characterized. These two compounds are intracellular chelators with two isomeric states. Various spiro-heterocyclic compounds were converted into the open chelating form of merocyanine, thus enhancing the antibacterial activity of $\beta$-lactams [127]. Then, researchers also verified that a range of spiro-indoline-thiadiazole analogs would potentiate $\beta$-lactam antibiotics on NDM-1positive K. pneumoniae in vitro by resisting zinc availability. Among analogs, compound 20 (20, Figure 8 ) inhibited NDM-1 in vitro and combined with meropenem, the bacterial load in the liver and spleen of mouse peritonea infected by NDM-1-expressing K. pneumoniae was significantly reduced [128].

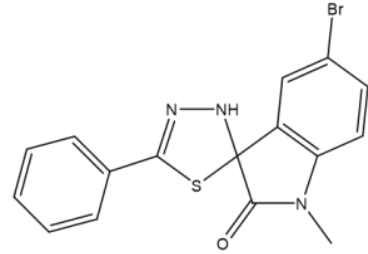

18

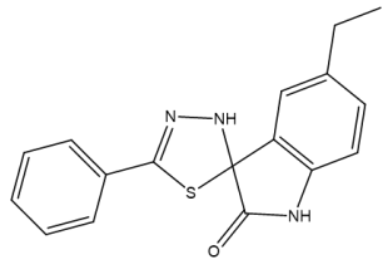

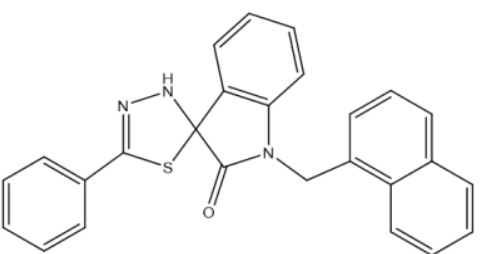

20

Figure 8. Thiadiazoles derivatives as NDM-1 inhibitors.

Isatin- $\beta$-thiosemicarbazones (IBT)

Repurposing old drugs is the most effective foundational method for the discovery of new drugs [129]. Isatin (21, Figure 9) is an endogenous natural product, and its derivatives possess antibacterial, antifungal, antimalarial and antiviral biological activities [130]. It was found that methisazone (22, Figure 9) was a weak NDM-1 inhibitor with an IC50 of $297.6 \mu \mathrm{M}$. Docking studies have shown that the thiol group present on the molecule forms several coordination bonds with zinc ions, indicating that thiol groups play an important role in the inhibition process. Inspired by this result, a series of IBT derivatives sharing the methisazone scaffold were designed and evaluated as new NDM-1 inhibitors. The IC50 values of the nine IBT derivatives were all below $10 \mu \mathrm{M}$, among which compound 23 (23, Figure 9) was the strongest at $2.72 \mu \mathrm{mol} / \mathrm{L}$ [131]. When new compounds were screened against drug-resistant bacteria, a few IBTs that can inhibit the growth of MRSA and VRE were also discovered, and their derivatives had significant activity against gram-positive bacteria. This finding indicated that IBTs can be regarded as potential lead compounds for discovering NDM-1 inhibitors [132].<smiles>O=C1Nc2ccccc2C1=O</smiles>

21 Isatin

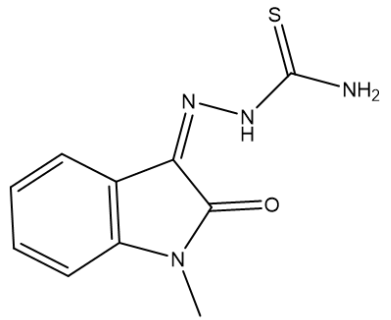

22 Methisazone

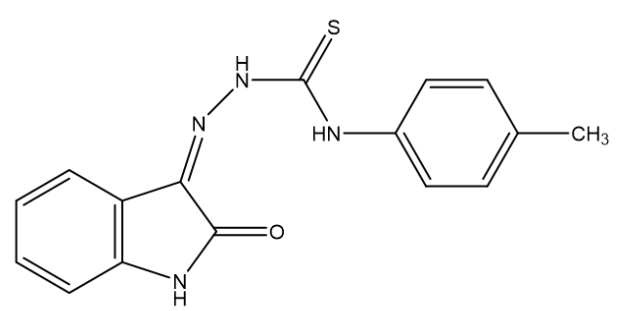

23

Figure 9. Isatin- $\beta$-thiosemicarbazones derivatives as NDM-1 inhibitors.

Pyridine Dicarboxylic Acid Derivatives

Chen and coworkers used a fragment-based NDM-1 inhibitor discovery strategy. 2,6-Dipicolinic acid (DPA, 24, Figure 10) was identified as a valuable chemical scaffold with an IC50 of $0.52 \mu \mathrm{M}$ and can be used to develop a novel type of broad-spectrum MBL inhibitor. The metal-binding pharmacophore (MBP) fragment library makes it possible 
to systematically search for compounds targeting the binuclear Zn site of B1 MBL and identify the DPA framework. The DPA core framework for further optimization and SAR analysis found that 4-(3-aminophenyl) pyridine-2,6-dicarboxylic acid (25, Figure 10) had an IC50 value of $80 \mathrm{nM}$. Further experiments demonstrated that DPA showed a tendency of chelation with metal ions from NDM-1 to form a stable ternary complex of NDM1:Zn(II):inhibitor, which acted as a metal-binding competitive inhibitor. When imipenem was used in combination with a DPA derivative, the resistance of Enterobacteriaceae producing NDM-1 to imipenem was reduced to a sensitive level [133].<smiles>O=C(O)c1cccc(C(=O)O)n1</smiles>

24 2,6-dipicolinic acid<smiles>Nc1cccc(-c2cc(C(=O)O)nc(C(=O)O)c2)c1</smiles>

25 4-(3-aminophenyl) pyridine-2,6-dicarboxylic acid<smiles>O=C(O)c1cccc(CP(=O)(O)O)n1</smiles>

26 PMPCs

Figure 10. Pyridine dicarboxylic acid derivatives as NDM-1 inhibitors.

Inspired by the DPA scaffold, Hinchliffe and coworkers designed and synthesized a series of 6-phosphonylmethylpyridine-2-carboxylic acid ester (PMPCs, 26, Figure 10) derivatives. According to bioelectronic isosteric theory, these derivatives substituted one of the carboxyl groups of DPA with a phosphonate. Without an isomerization step, the inhibitor competitively and slowly bound to NDM-1, with low IC50 values of 0.3-7.2 mM. SAR studies have indicated that both carboxylic and phosphonic acids are important pharmacophores for inhibiting NDM-1. When carboxylic or phosphonic acid exists alone, its inhibitory activity is greatly reduced. PMPCs inhibit NDM-1 by binding to the active site, not just by chelating metal ions. The efficacy, low toxicity, and affinity of PMPCs indicated that PMPCs and similar phosphonate compounds may be considered for the development of NDM-1 inhibitors [134].

\section{Triazole-Thione Derivatives}

Triazole thiones (27, Figure 11) are commonly reported as synthetic intermediates and have antibacterial, antiproliferative, and anti-inflammatory biological activity [135]. 1,2,4-Triazole-3-thione derivatives as metal ligands have been confirmed to inhibit clinically relevant MBLs, which are well adapted to target the catalytic site of di-zinc MBLs [136]. Based on the triazole-thione scaffold, fifty-four analogs of initial compounds 28 and 29 (28, 29 , Figure 11) differing on their side chain at position 5 of the heterocycle were synthesized and evaluated, and identified. Nineteen inhibitors with an IC50 in the $\mu \mathrm{M}$ range toward at least one of the MBLs and five analogs inhibited at least four enzymes [137]. Recently, ninety 4-amino-1,2,4-triazole-3-thione-derived (30, Figure 10) bases were synthesized and characterized, and they changed at the 4th and 5th positions. The existence of the 4-position aryl moiety increased the potency by an average of 10 times. Several compounds are broad-spectrum inhibitors of MBLs, and compound 31 (31, Figure 11) was combined with colistin to restore the activity of colistin against NDM-1 clinical isolates [138]. 
<smiles>[R]c1n[nH]c(=S)n1[R]</smiles>

27 Triazole-thiones<smiles>Cc1ccc(-c2n[nH]c(=S)n2N)cc1C</smiles><smiles>Cc1ccc(-c2n[nH]c(=S)[nH]2)cc1C</smiles>

29<smiles>[R]C=Nn1c([R8])n[nH]c1=S</smiles>

30 4-amino-1,2,4-triazole-3-thione

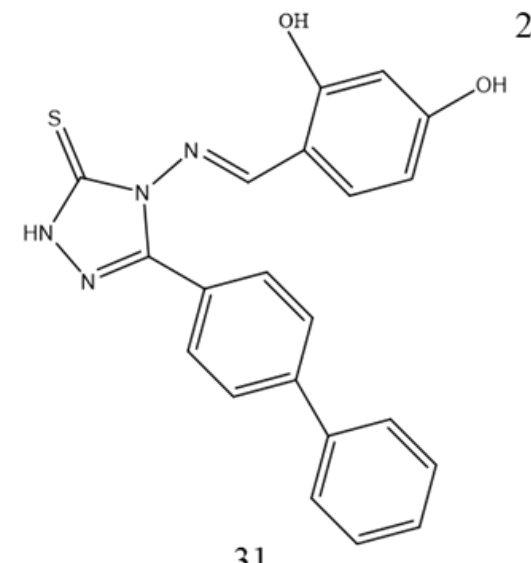

31

Figure 11. Triazole-thione derivatives as NDM-1 inhibitors.

\subsubsection{Boronic Acid Derivatives}

Since bortezomib was approved by the US FDA, borate compounds have been utilized as a new scaffold for $\beta$-lactamase inhibitor development. The boron atom in boronic acid is sp3 hybridized under physiological $\mathrm{pH}$, and the geometric structure of the tetrahedron can fully simulate the instantaneous tetrahedral species formed in the catalytic process of hydrolytic enzymes [139]. Brem et al. reported that cyclic boronates, the first dual BL inhibitor, significantly inhibited both nucleophilic SBLs and zinc-dependent MBLs by imitating the common tetrahedral intermediate produced during the hydrolysis reaction. All five derivatives showed submicron/nanomolar inhibitor activity against NDM-1. It should be noted that with the combined use of compounds 32 and 33 (32, 33, Figure 12), the MIC of meropenem in all NDM-1-producing strains was reduced by up to 64 times. The X-ray crystallography structures of the B1 MBL complex with 34 (34, Figure 12) showed that first, the C-3 carboxylate oxygen interacts with both Zn2 and Lys224 (NDM-1 and BcII) or Arg228 (VIM-2). Second, the bicyclic phenyl-boronate ring of compound 34 on the active site of MBLs can interact hydrophobically with the conserved Trp87 and Phe61 residues. Finally, the two 'exocyclic' boron-binding hydroxyls coordinate with $\mathrm{Zn} 1$ and form hydrogen bonds with Asn233 and the NH of the acetylamino side chain. Cyclic boronates also potently inhibit the PBP targets of BLAs by the same mechanism of action [140]. 


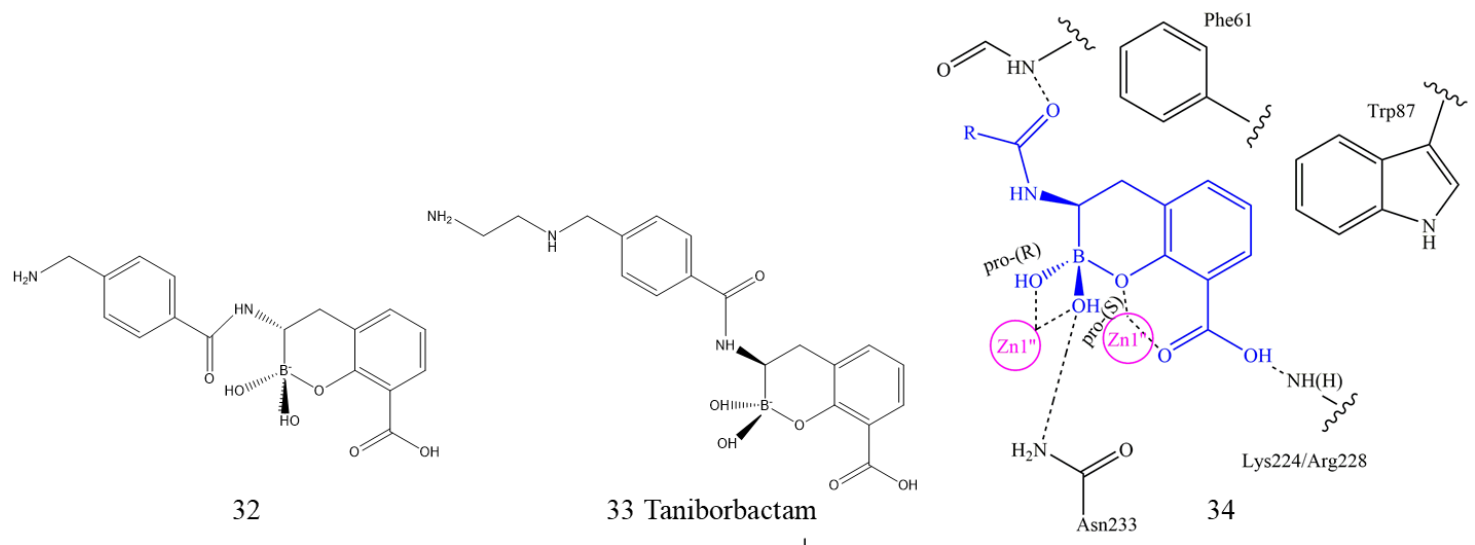<smiles>[2H][C@]12C[C@]1(C)B(O)Oc1c2ccc(F)c1C(=O)O</smiles>

35 QPX7728<smiles>OB(O)c1cc2ccccc2s1</smiles>

36 BZB

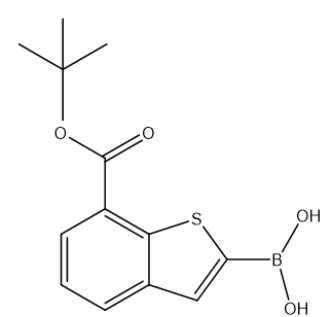

37

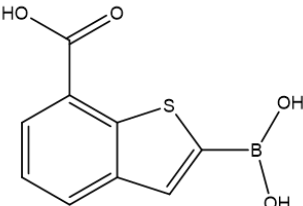

Figure 12. Boronic acid derivatives as NDM-1 inhibitors.

The promotion effect of cyclic boron was further studied. By modifying the key structure of the bicyclic aromatic ring, methyl thioacetamide was found to be one of the most active imide substituents. By modifying the key structure, the compound QPX7728 (35, Figure 12) was ultimately obtained with a hydrophobic region composed of oleophilic side chains. QPX7728 displays ultrabroad-spectrum inhibition of SBL and MBL enzymes and is less influenced by modifications and efflux of the porin. In the complex crystal structures of QPX7728 with NDM-1, the catalytic water molecule is covalently bound to the boron atom of QPX7728. Due to the favorable bioavailability and biosafety of QPX7728, it is suitable for combined application with $\beta$-lactam antibiotics for the treatment of multidrug-resistant bacterial infections. The drug is currently in the late stage of preclinical development [141].

Starting from benzo-[b]-thiophene-2-boronic acid (BZB, 36 Figure 12) as an inhibitor of AmpC $\beta$-lactamase, Santucci et al. reported for the first time that a multiligand set of acyclic boronic acid of BZB analogs was able to inhibit clinically relevant BLs, including NDM-1. All the acyclic boronic acid analogs had low SBL micromolar inhibitor activity, while compounds 37 and 38 (37, 38, Figure 12) showed activity toward NDM-1 with IC50 values of $35.7 \mu \mathrm{M}$ and $32.4 \mu \mathrm{M}$, respectively. Docking simulations suggested that the boronic group of derivatives coordinated two metal zinc ions, and the carboxyl groups interacted with key catalytic residues to form hydrogen bonds [142].

Both cyclic and acyclic boronic acids showed favorable NDM-1 inhibitory activity; however, the activity of the former was significantly stronger than that of the latter due to the double-ring structure of cyclic boric acid. Among them, compound 33 (taniborbactam, VNRX5133) with a dual-ring structure has been approved by the FDA to enter phase III clinical trials [143]. Taniborbactam is also a dual BLs inhibitor. The crystallographic results emphasize the ability of bicyclic borate to inhibit SBLs and MBLs by combining with tetrahedral (sp3) boron. The results further support boronic acid as a scaffold to design broad-spectrum BL inhibitors.

\subsubsection{Metal Chelating Inhibitors}

The main element of zinc-dependent enzyme inactivation is zinc deprivation, so it has been widely reported that metal complexing agents show MBL enzyme inhibition activity [144]. For example, ethylenediaminetetraacetic acid (EDTA, 39, Figure 13) is an 
MBL inhibitor with the function of sequestering and extracting key zinc in the active site, thus protecting the coadministered antibiotic from hydrolysis. Studies have shown that NDM-1 is more sensitive to EDTA than other MBLs, with an IC50 of $0.4 \mu \mathrm{M}$, indicating that EDTA possesses a strong ability to bind the Zn ions of NDM-1 [145]. Other metal chelators, 1,4,7-triazacyclononane-1,4,7-triacetic acid (NOTA, 40, Figure 13) and 1,4,7,10tetra-azacyclononane-1,4,7,10-tetraacetic acid (DOTA, 41, Figure 13), demonstrated activity against NDM-1-producing bacteria. NOTA was more effective than DOTA in restoring antibiotic susceptibility [146]. Despite these promising effects, the toxicity of these nonselective chelating agents prevents them from being widely used in the clinic because they can chelate various metal ions, such as $\mathrm{Zn}, \mathrm{Fe}$, and $\mathrm{Cu}$. $\mathrm{Zn}$ is the key element of essential enzymes, and excessive consumption of $\mathrm{Zn}$ by metal chelating agents may lead to disease [147]. An important exception was disodium calcium salt (Ca-EDTA, 42, Figure 12). It was reported that Ca-EDTA greatly reduced toxicity and was approved as an injection in Japan for the treatment of lead poisoning. Ca-EDTA significantly reduced the MICs of carbapenem antibiotics against all NDM-1-overexpressing bacteria. In a mouse model of sepsis, Ca-EDTA combined with imipenem and CILAStatin sodium treatment further reduced the bacterial load compared with imipenem or CILAStatin sodium treatments alone [105].

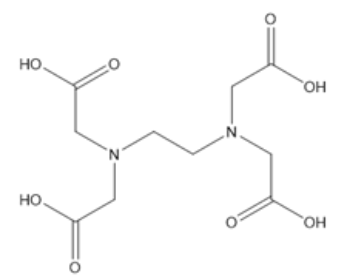

39 EDTA

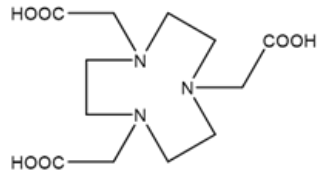

40 NOTA

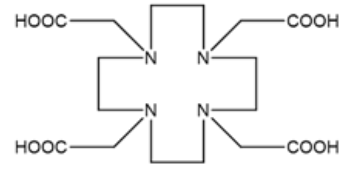

41 DOTA

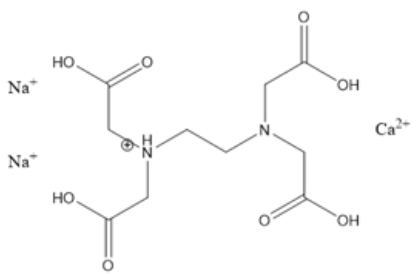

42 Ca-EDTA

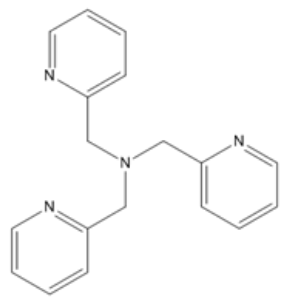

43 TPA<smiles>NC(CNC(CNC(CC(=O)O)C(=O)O)C(=O)O)C(=O)O</smiles>

45 AMA<smiles>c1ccc(CN(Cc2ccccn2)Cc2ccccn2)nc1</smiles>

44 TFA<smiles>N[C@@H](CN[C@@H](CN[C@H](CC(=O)O)C(=O)O)C(=O)O)C(=O)O</smiles>

46 (S, S,S ) AMA

Figure 13. Metal chelating as NDM-1 inhibitors.

Schnaars et al. synthesized several novel selective zinc chelators based on a trispicolylamine (TPA, 43, Figure 13) scaffold as putative MBL inhibitors. All new derivatives reduced the MIC of meropenem against MBL-harboring carbapenem-resistant strains and reduced HepG2 toxicity. Among them, one of the most promising compounds (TFA, 44, Figure 13) reduced the MIC of meropenem in MBL-expressing isolates and showed no activity on carbapenem serine-expressing strains, which indirectly demonstrated that $\mathrm{Zn}$ chelation of TPA had occurred.

King and coworkers established a cell-based NDM-1 inhibitor screening model by using natural product extracts from environmental microorganisms [104]. NDM-1 inhibitors were 
screened by the model strain [E. coli BW25113 $\Delta$ bamB $\Delta$ tolC $\Delta$ araDAB: pLac(blaNDM-1)] in combination with a sublethal concentration of meropenem. Aspergillomarasmine A (AMA, 45, Figure 13) was identified from approximately 500 natural product extracts. It is a natural product that was isolated from the extract of Aspergillus versicolor fungus, which was an inhibitor of ACE and endothelin converting enzyme [148,149]. AMA had a highly selective inhibitory effect on NDM-1, with an IC50 of $4.1 \pm 1.0 \mu \mathrm{M}$ and Ki of $11 \mu \mathrm{M}$. The activity of meropenem on bacteria overexpressing NDM-1 was completely restored, but it was completely ineffective on SBLs. In contrast to the metal complexing agents mentioned above, AMA can also maintain efficacy in vivo. The survival study of mice showed that the bacterial load of NDM-1-positive K. pneumoniae in tissues was not affected by treatment with AMA and meropenem alone, while the combined treatment of AMA $\left(10 \mathrm{mg} \cdot \mathrm{kg}^{-1}\right)$ and meropenem $\left(10 \mathrm{mg} \cdot \mathrm{kg}^{-1}\right)$ significantly reduced the bacterial load in the spleen, and the 5-day survival rates were increased to 95\%. Surprisingly, compared with the $50 \%$ lethal dose (LD50) of EDTA of $29 \mathrm{mg} \cdot \mathrm{kg}^{-1}$, AMA exhibited low toxicity with an LD50 of $159.8 \mathrm{mg} \cdot \mathrm{kg}^{-1}$. The inhibition of NDM-1 by AMA is irreversible, but the activity of the enzyme could be restored by adding excessive $\mathrm{ZnSO} 4$, which is consistent with a metal depletion mechanism. AMA represents a nontoxic candidate for an antibiotic adjuvant, and its high hydrophilicity with a CLog $P$ value of -5 may limit further development and application in the clinic [104].

Soon after, Wright and coworkers completed the stereoselective total synthesis of AMA molecules, reassigned the absolute configuration of the three stereocenters to ( $S$, $S, S)$, and corrected the configuration $(R, R, S)$ proposed by King for the first time. ( , $S, S)-A M A(46$, Figure 13) had the same inhibitory activity against NDM-1 as the first natural extract [150]. Seven new AMA derivatives were efficiently synthesized by different strategies. SAR studies clearly showed that the aspartic acid part of AMA and the carboxyl groups in C1, C4, C6, and C9 play a key role in NDM-1 inhibition. The combination of AMA derivatives and meropenem had a synergistic effect on the drug resistance of NDM-1-expressing K. pneumoniae and other gram-negative bacteria [151].

\subsection{Covalently Bound Inhibitors}

NDM-1 has a Cys208 residue, which is an essential residue for the coordination with zinc ions to maintain a conserved active site structure, so this residue can potentially be a target in the design of NDM-1 inhibitors. Thomas et al. authenticated two irreversible thiol-modifying p-chloromercuribenzoate acids (p-CMB, 47, Figure 14) and nitroprusside (48, Figure 14) as NDM-1 inhibitors through high-throughput screening, which can be irreversibly covalently bound to the Cys208 residue on NDM-1 and exhibit inhibitory activity with IC50 values of 2.3 and $9.0 \mu \mathrm{M}$, respectively. Almost all enzyme activity was maintained despite the C208D mutation, and it was completely resistant to inhibitors. This acquirable resistance mutation demonstrated that covalent targeting of the conserved active-site Cys residue may have drawbacks as an NDM-1 inhibitor design strategy [152]. 
<smiles>N#C[N+](=O)C(C#N)(C#N)C#N</smiles>

47 p-CMB<smiles>CC(C)(C)OC(=O)NCCn1[se]c2ccccc2c1=O</smiles>

50<smiles>NC(C(=O)NC1C(=O)N2C(C(=O)O)=C(Cl)CSC12)c1ccccc1</smiles>

53 Cefaclor
48 Nitroprusside<smiles>O=c1c2ccccc2sn1-c1ccccc1</smiles>

51 Ebsulfur<smiles>N#Cc1coc2ccccc2c1=O</smiles>

54 3-Formylchromone<smiles></smiles>

49 Ebselen<smiles></smiles>

52 3-Bromopyruvate<smiles>O=C(CONC(=O)Oc1ccccc1)OCc1ccccc1</smiles>

55 O-aryloxycarbonyl hydroxamate

Figure 14. Covalently bound inhibitors of NDM-1.

Ebselen (2-phenyl-1,2-benzoselenazol-3-one, 49, Figure 14) is a compound containing selenium used for the treatment of cerebral ischemia and stroke. It has also been shown to be a promising NDM-1 inhibitor by a cell-based screening method [153]. Enzymatic kinetic studies and ESI-MS analyses showed that ebselen could form a covalent S-Se bond with the Cys208 residue to binding to NDM-1, resulting in the removal of Zn2 from the active site, demonstrating a new inhibition mechanism and broad-spectrum inhibitory potential. In vitro, ebselen coadministration with meropenem resulted in 128 -fold reductions in the MICs, thus restoring the activity of meropenem on NDM-1-positive E. coli [154]. A total of forty-six 1,2-benzisoselenazol-3(2H)-one scaffold derivatives were treated with ebselen, and many compounds displayed stronger synergistic activity with meropenem and better physiochemical properties than those of ebselen. Among them, compound 50 (50, Figure 14) could covalently bind to NDM-1 and transfer one zinc ion from the active site, showing strong synergistic activity with meropenem against clinical NDM-1 CRE isolates [155].

$\mathrm{Su}$ et al. further reported a potent covalent scaffold ebsulfur (51, Figure 14). Eighteen ebsulfur derivatives targeted NDM-1 with IC50 values ranging from 0.16 to $9 \mu \mathrm{M}$ and effectively reversed the antibacterial activity of cefazolin against E. coli expressing NDM-1. Inhibition and equilibrium dialysis studies showed that there was a covalent and timedependent relationship between ebsulfur and NDM-1 [156].

3-Bromopyruvate (52, Figure 14) is an active reactive electrophilic derivative of pyruvate, a cell metabolite that is clinically used for cancer treatment [157]. It has also been demonstrated to exhibit potential inhibitory activity on B1 and B2 MBLs, especially on NDM-1, with an IC50 of $2.57 \mu \mathrm{M}$. In addition, among the three clinical isolates that were NDM-1 positive, 3-bromopyruvate effectively restored the activity and reduced the MIC of five $\beta$-lactams antibiotics, such as cefotaxime and meropenem. A study on the inhibition mechanism suggested that 3-bromopyruvate may reversibly inhibit NDM-1 by covalently binding electrophilic methylene with Cys208 at the active center of NDM-1 [158]. 
Along this line of research, the Lys211 residue was also considered to be a promising "handhold" for the development of NDM-1 covalent inhibitors. Thomas et al. reported that the $\beta$-lactam drug cefaclor (53, Figure 14$)$ is a time- and concentration-dependent covalent irreversible inactivator of NDM-1 with millimolar affinity. Cefaclor inactivation is mediated by a variety of pathways, including mediation by Lys211. Surprisingly, cefaclor was also demonstrated to be more effective as the substrate of NDM-1 than as an inactivator. Unfortunately, supratherapeutic doses of cefaclor are required to achieve NDM-1 inactivation in vitro, which hinders its clinical use against NDM-1 [159]. 3-Formylchromone (54, Figure 14) was identified as a novel covalent inhibitor of clinically relevant MBLs. The results of ESI-MS and single-site directed mutagenesis showed that cefaclor and Lys221 formed a covalent bond at the active site of NDM-1, while Lys211 is highly conserved and adjacent to the metal cluster of NDM-1 [160]. Recently, Thomas et al. also reported O-aryl oxycarbonyl hydroxamate (55, Figure 14) as a classical affinity label for NDM-1, which was bound with Lys211 in the substrate-binding site of NDM-1 [161].

\subsection{Inhibitors with Other Mechanisms}

In contrast to the screening and design philosophy of other NDM-1 inhibitors, Sully et al. constructed a peptide-conjugated phosphorodiamidate morpholino oligomer (PPMO) targeting NDM-1 mRNA and intervened in the expression of NDM-1 at the gene level. PPMO restored the sensitivity of NDM-1-positive strains to carbapenems in vitro. In a murine sepsis model infected with E. coli expressing blaNDM-1, PPMO in combination with meropenem significantly improved the survival rate, reduced the systemic bacterial burden, and alleviated inflammation. PPMO is a gene-specific therapeutic targeted to NDM-1, and this new strategy can rapidly design, synthesize and test sequence specificity against bacterial gene targets [162].

Chandar et al. screened ethanol extracts against the NDM-1 E. coli strain from the leaves of 240 medicinal plant species. Then, extracts from six plants, including Hibiscus acetosella, Punica granatum, and Combretum albidum, showed inhibitory activity on NDM1 with an IC50 value ranging from 0.50 to $1.2 \mathrm{ng} / \mu \mathrm{L}$, and the MIC was between 2.56 and $5.12 \mathrm{mg} / \mathrm{mL}$. The mechanism of plant extracts inhibits NDM-1 enzyme activity by destroying the integrity of bacterial cell walls. When used in combination with antibiotics with FICI values of $0.09-0.375$, all the plant extracts showed synergistic effects, which indicated the possibility of combined treatment with NDM-1 bacteria [163].

ANT431 (56, Figure 15), a specific competitive inhibitor of MBLs, is the result of design modifications based on the lead compound pyridine-2-carboxylic acid. ANT431 competitively inhibited the activity of NDM-1 and VIM-2 with Ki values of 0.29 and $0.195 \mu \mathrm{M}$, respectively. When the concentration of ANT431 was $30 \mu \mathrm{g} / \mathrm{mL}$, it remarkably improved the activity of meropenem on recombinant NDM-1-positive engineered bacteria and reduced meropenem MICs to EUCAST breakpoint susceptibility levels in over $70 \%$ of highly resistant relevant clinical isolates. In a murine thigh infection model, meropenem in combination with ANT431 restored the efficacy of meropenem against E. coli NDM1-producing bacteria. Compared with other metalloenzymes, such as ACE and GLY2, ANT431 displayed favorable selectivity and pharmacokinetic profile, which showed a high potential of patent medicine [164]. 


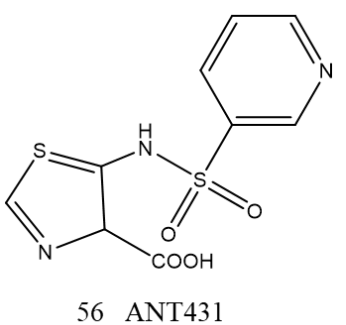

56 ANT431

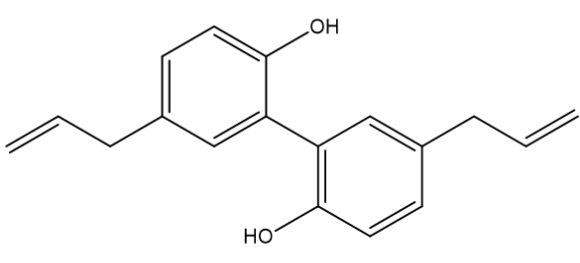

57 Magnolol

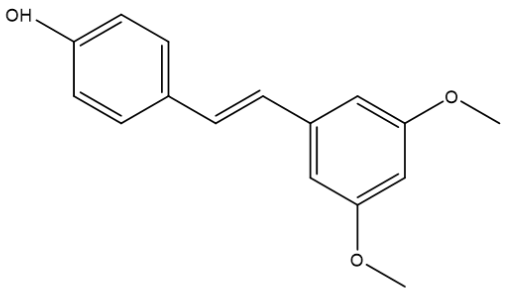

58 Pterostilbene

Figure 15. Other mechanisms inhibitors of NDM-1.

Liu et al. discovered two potent NDM-1 inhibitors that interact with amino acid residues. Magnolol (57, Figure 15), a natural product separated from the bark of magnolia trees, significantly inhibited the biological activity of NDM-1 with an IC50 value of $6.47 \mu \mathrm{g} / \mathrm{mL}$ and restored the effectiveness of meropenem in vitro against NDM-1producing E. coli. The compound pterostilbene (58, Figure 15), which was originally isolated from red sandalwood, showed a synergistic inhibitory effect with meropenem against NDM-1-positive E. coli. The mechanistic analysis demonstrated that magnolol and pterostilbene were directly located in the catalytic pocket of NDM-1 and formed hydrogen bonds or hydrophobic interactions, thereby hindering substrate binding to NDM-1 and resulting in its inactivation. Furthermore, they inhibited the activity of NDM-1 without influencing the binding of NDM to Zn, which was different from the metal consumption mechanisms of other inhibitors $[165,166]$.

Finally, novel synthetic peptide inhibitors were found and characterized by the surface localized antimicrobial display (SLAY), which enhanced the killing effect of carbapenem on NDM-1 E. coli. Approximately 1700 candidate peptide sequences were identified, among which only 37 peptides restored NDM-1-producing E. coli sensitivity to both meropenem and imipenem. Sequence analysis of 37 peptides showed that their specific amino acids were enriched, and each sequence encoded a residue with a positive charge. Conservative site-specific charge was helpful for peptides to penetrate the periplasm of bacteria and directly bind NDM-1 to inhibit enzymatic activity [167]. This approach provides a molecular platform for the discovery of NDM-1 inhibitors.

\section{Conclusions}

Over the past decade, NDM-1 and its variants have rapidly spread around the world. The gram-negative strain that produces NDM-1 poses a major public health threat because it can catalyze the hydrolysis of a variety of $\beta$-lactam antibiotics, including carbapenems, which is the last choice to treat infections caused by drug-resistant bacteria. Therefore, the active discovery of highly effective inhibitors and combination with $\beta$-lactam antibiotics has become an important strategy against NDM-1-expressing drug-resistant bacteria. Although a series of studies have been carried out on the structural characteristics, biological functions, and mechanism of action of NDM- 1 in the past few years, none of the NDM-1 inhibitors have yet been approved for clinical application. The unclear catalytic mechanism of NDM- 1 enzymes and various hydrolysis mechanisms of $\beta$-lactam antibiotics are crucial factors that hinder the development of NDM- 1 inhibitors. The active site of NDM- 1 gives the enzyme the characteristic that allows it to bind to a wide range of substrates, but the specific binding mode of NDM-1 to different substrates is different, which increases the difficulty in establishing the targeted active site inhibitor. Hopefully, with the development of computational biology, pharmaceutical chemistry, and other multidisciplinary knowledge and technology, the interaction mode of NDM-1 and substrate will be explained more accurately and thoroughly.

At present, compounds that can not only chelate zinc ions at the active site of NDM-1 but also form hydrogen bonds and/or salt bridges with amino acid residues at the binding site are the most promising inhibitors of NDM-1. Moreover, there are many metallo- 
proteinases in the human body, and compounds targeting NDM-1 rather than human metalloproteinases may be prerequisites for the development of NDM-1 inhibitors in the future. At the same time, mutating NDM-1 tends to enhance the affinity of zinc ions in vivo and improve the tolerance to $\mathrm{Zn}$ deprivation, which poses a new challenge for the development of inhibitors in the future. In this paper, the overview of the superbug NDM-1 and the research progress of inhibitors provided are powerful references for the discovery and optimization of new inhibitors. Moreover, this review could provide MBL inhibitorcarbapenem combination strategies that complement the existing weaponry against CRE, with profound influence on human health.

Author Contributions: Writing original draft and review, X.L. and X.Z.; Resources and data curation, D.Z. and W.L.; Software and visualization, J.S.; Supervision and editing, X.Z. All authors have read and agreed to the published version of the manuscript.

Funding: This work was supported by the National 13th Five-Year Key R\&D Program Special, Project under Grant: 2018YFD0500306.

Conflicts of Interest: The authors declare no conflict of interest.

\section{References}

1. Scallan, E.; Hoekstra, R.M.; Angulo, F.J.; Tauxe, R.V.; Widdowson, M.A.; Roy, S.L.; Jones, J.L.; Griffin, P.M. Foodborne illness acquired in the United States-Major pathogens. Emerg. Infect. Dis. 2011, 17, 7-15. [CrossRef]

2. De Graaf, M.; van Beek, J.; Koopmans, M.P. Human norovirus transmission and evolution in a changing world. Nat. Rev. Microbiol. 2016, 14, 421-433. [CrossRef]

3. Hu, X.; Collier, M.G.; Xu, F. Hepatitis a outbreaks in developed countries: Detection, control, and prevention. Foodborne Pathog. Dis. 2020, 17, 166-171. [CrossRef]

4. Richter, M.F.; Hergenrother, P.J. The challenge of converting Gram-positive-only compounds into broad-spectrum antibiotics. Ann. N. Y. Acad. Sci. 2019, 1435, 18-38. [CrossRef] [PubMed]

5. Cornejo-juárez, P.; Vilar-compte, D.; Pérez-jiménez, C.; Ñamendys-Silva, S.A.; Sandoval-Hernández, S.; Volkow-Fernández, P. The impact of hospital-acquired infections with multidrug-resistant bacteria in an oncology intensive care unit. Int. J. Infect. Dis. 2015, 31, 31-34. [CrossRef]

6. Karaiskos, I.; Lagou, S.; Pontikis, K.; Rapti, V.; Poulakou, G. The "Old" and the "New" Antibiotics for MDR Gram-Negative Pathogens: For Whom, When, and How. Front. Public Health 2019, 7, 151-176. [CrossRef]

7. De Kraker, M.E.; Stewardson, A.J.; Harbarth, S. Will 10 million people die a year due to antimicrobial resistance by 2050 ? PLoS Med. 2016, 13, e1002184. [CrossRef]

8. Bush, K.; Bradford, P.A. $\beta$-Lactams and $\beta$-Lactamase inhibitors: An overview. Cold Spring Harb. Perspect. Med. 2016, 6, a025247. [CrossRef] [PubMed]

9. Sauvage, E.; Kerff, F.; Terrak, M.; Ayala, J.A.; Charlier, P. The penicillin-binding proteins: Structure and role in peptidoglycan biosynthesis. FEMS Microbiol. Rev. 2008, 32, 234-258. [CrossRef] [PubMed]

10. King, D.T.; Sobhanifar, S.; Strynadka, N. The Mechanisms of Resistance to $\beta$-Lactam Antibiotics; Springer: New York, NY, USA, 2014

11. Essack, S.Y. The development of beta-lactam antibiotics in response to the evolution of beta-lactamases. Pharm. Res. 2001, 18, 1391-1399. [CrossRef] [PubMed]

12. Bush, K. Past and present perspectives on $\beta$-lactamases. Antimicrob. Agents Chemother. 2018, 62, e01076-18. [CrossRef] [PubMed]

13. Ambler, R.P. The structure of beta-lactamases. Philos. Trans. R. Soc. B. 1980, 289, 321-331.

14. Al-sehlawi, Z.; Almohana, A.; Al-thahab, A. Ampc $\beta$-Lactamases. Clin. Microbiol. Rev. 2009, 22, 161-182.

15. Tondi, D.; Cross, S.; Venturelli, A.; Costi, M.P.; Cruciani, G.; Spyrakis, F. Decoding the structural basis for carbapenem hydrolysis by class a $\beta$-lactamases: Fishing for a pharmacophore. Curr. Drug Targets 2016, 17, 983-1005. [CrossRef]

16. Docquier, J.D.; Mangani, S. Structure-function relationships of class d carbapenemases. Curr. Drug Targets 2016, 17, 1061-1071. [CrossRef]

17. Shimada, A.; Ishikawa, H.; Nakagawa, N.; Kuramitsu, S.; Masui, R. The first crystal structure of an archaeal metallo-beta-lactamase superfamily protein; ST1585 from Sulfolobus tokodaii. Proteins 2010, 78, 2399-2402. [CrossRef] [PubMed]

18. Bebrone, C. Metallo-beta-lactamases (classification, activity, genetic organization, structure, zinc coordination) and their superfamily. Biochem. Pharmacol. 2007, 74, 1686-1701. [CrossRef] [PubMed]

19. Palzkill, T. Metallo- $\beta$-lactamase structure and function. Ann. N. Y. Acad. Sci. 2013, 1277, 91-104. [CrossRef]

20. Garau, G.; García-Sáez, I.; Bebrone, C.; Anne, C.; Mercuri, P.; Galleni, M.; Frère, J.M.; Dideberg, O. Update of the standard numbering scheme for class B beta-lactamases. Antimicrob. Agents Chemother. 2004, 48, 2347-2349. [CrossRef] [PubMed]

21. Walsh, T.R.; Weeks, J.; Livermore, D.M.; Toleman, M.A. Dissemination of NDM-1 positive bacteria in the New Delhi environment and its implications for human health: An environmental point prevalence study. Lancet Infect. Dis. 2011, 11, 355-362. [CrossRef] 
22. Yong, D.; Toleman, M.A.; Giske, C.G.; Cho, H.S.; Sundman, K.; Lee, K.; Walsh, T.R. Characterization of a new metallo-betalactamase gene, bla(NDM-1), and a novel erythromycin esterase gene carried on a unique genetic structure in Klebsiella pneumoniae sequence type 14 from India. Antimicrob. Agents Chemother. 2009, 53, 5046-5054. [CrossRef]

23. Rolain, J.M.; Parola, P.; Cornaglia, G. New Delhi metallo-beta-lactamase (NDM-1): Towards a new pandemia? Clin. Microbiol. Infect. 2010, 16, 1699-1701. [CrossRef] [PubMed]

24. Cornaglia, G.; Giamarellou, H.; Rossolini, G.M. Metallo- $\beta$-lactamases: A last frontier for $\beta$-lactams? Lancet Infect. Dis. 2011, 11, 381-393. [CrossRef]

25. Kumarasamy, K.K.; Toleman, M.A.; Walsh, T.R.; Bagaria, J.; Butt, F.; Balakrishnan, R.; Chaudhary, U.; Doumith, M.; Giske, C.G.; Irfan, S.; et al. Emergence of a new antibiotic resistance mechanism in India, Pakistan, and the UK: A molecular, biological, and epidemiological study. Lancet Infect. Dis. 2010, 10, 597-602. [CrossRef]

26. Moellering, R.C. NDM-1-a cause for worldwide concern. N. Engl. J. Med. 2010, 363, 2377-2379. [CrossRef] [PubMed]

27. Linciano, P.; Cendron, L.; Gianquinto, E.; Spyrakis, F.; Tondi, D. Ten years with new delhi metallo- $\beta$-lactamase- 1 (ndm-1): From structural insights to inhibitor design. ACS Infect. Dis. 2019, 5, 9-34. [CrossRef] [PubMed]

28. Potron, A.; Poirel, L.; Nordmann, P. Plasmid-mediated transfer of the blaNDM-1 gene in Gram-negative rods. Fems. Microbiol. Lett. 2011, 324, 111-116. [CrossRef]

29. Zubair, M. Microbiology of diabetic foot ulcer with special reference to ESBL infections. Am. J. Clin. Exp. Med. 2015, 3, 6-23. [CrossRef]

30. Lubick, N. Antibiotic resistance shows up in India's drinking water. Nature 2011, 218. [CrossRef]

31. Pan, C.Y.; Chen, J.C.; Chen, T.L.; Wu, J.L.; Hui, C.F.; Chen, J.Y. Piscidin is highly active against carbapenem-resistant Acinetobacter baumannii and NDM-1-producing Klebsiella pneumonia in a systemic Septicaemia infection mouse model. Mar. Drugs 2015, 13, 2287-2305. [CrossRef]

32. Albur, M.; Noel, A.; Bowker, K.; MacGowan, A. Bactericidal activity of multiple combinations of tigecycline and colistin against NDM-1-producing Enterobacteriaceae. Antimicrob. Agents Chemother. 2012, 56, 3441-3443. [CrossRef] [PubMed]

33. Rimrang, B.; Chanawong, A.; Lulitanond, A.; Wilailuckana, C.; Charoensri, N.; Sribenjalux, P.; Phumsrikaew, W.; Wonglakorn, L.; Chetchotisakd, P. New Delhi metallo- $\beta$-lactamase-1 (NDM-1)-producing enterobacteriaceae: First report in Thailand. Int. J. Infect. Dis. 2012, 16, e431. [CrossRef]

34. Charan, J.; Mulla, S.; Ryavanki, S.; Kantharia, N. New Delhi Metallo-beta lactamase-1 containing enterobacteriaceae: Origin, diagnosis, treatment and public health concern. Pan. Afr. Med. J. 2012, 11, 22. [PubMed]

35. Zhang, H.; Hao, Q. Crystal structure of NDM-1 reveals a common $\beta$-lactam hydrolysis mechanism. FASEB J. 2011, $25,2574-2582$. [CrossRef] [PubMed]

36. Guo, Y.; Wang, J.; Niu, G.; Shui, W.; Sun, Y.; Zhou, H.; Zhang, Y.; Yang, C.; Lou, Z.; Rao, Z. A structural view of the antibiotic degradation enzyme NDM-1 from a superbug. Protein Cell 2011, 2, 384-394. [CrossRef]

37. Kim, Y.; Tesar, C.; Mire, J.; Jedrzejczak, R.; Binkowski, A.; Babnigg, G.; Sacchettini, J.; Joachimiak, A. Structure of apo- and monometalated forms of NDM-1-A highly potent carbapenem-hydrolyzing metallo- $\beta$-lactamase. PLoS ONE 2011, 6, e24621. [CrossRef] [PubMed]

38. Chiou, J.; Leung, Y.C.; Chen, S. Molecular mechanisms of substrate recognition and specificity of New Delhi metallo-ß-lactamase Antimicrob. Agents Chemother. 2014, 58, 5372-5378. [CrossRef] [PubMed]

39. Thomas, P.W.; Zheng, M.; Wu, S.; Guo, H.; Liu, D.; Xu, D.; Fast, W. Characterization of purified New Delhi metallo- $\beta$-lactamase-1. Biochemistry 2011, 50, 10102-10113. [CrossRef]

40. King, D.; Strynadka, N. Crystal structure of New Delhi metallo- $\beta$-lactamase reveals molecular basis for antibiotic resistance. Protein Sci. 2011, 20, 1484-1491. [CrossRef]

41. Rose, P.W.; Bi, C.; Bluhm, W.F.; Christie, C.H.; Dimitropoulos, D.; Dutta, S.; Green, R.K.; Goodsell, D.S.; Prlic, A.; Quesada, M.; et al. The RCSB Protein Data Bank: New resources for research and education. Nucleic Acids Res. 2013, 41, D475-D482. [CrossRef]

42. King, D.T.; Worrall, L.J.; Gruninger, R.; Strynadka, N.C. New Delhi metallo- $\beta$-lactamase: Structural insights into $\beta$-lactam recognition and inhibitio. J. Am. Chem. Soc. 2012, 134, 11362-11365. [CrossRef] [PubMed]

43. Zheng, M.; Xu, D. New Delhi metallo- $\beta$-lactamase I: Substrate binding and catalytic mechanism. J. Phys. Chem. B. 2013, 117, 11596-11607. [CrossRef] [PubMed]

44. Feng, H.; Ding, J.; Zhu, D.; Liu, X.; Xu, X.; Zhang, Y.; Zang, S.; Wang, D.C.; Liu, W. Structural and mechanistic insights into NDM-1 catalyzed hydrolysis of cephalosporins. J. Am. Chem. Soc. 2014, 136, 14694-14697. [CrossRef]

45. González, M.M.; Kosmopoulou, M.; Mojica, M.F.; Castillo, V.; Hinchliffe, P.; Pettinati, I.; Brem, J.; Schofield, C.J.; Mahler, G.; Bonomo, R.A.; et al. Bisthiazolidines: A Substrate-Mimicking Scaffold as an Inhibitor of the NDM-1 Carbapenemase. ACS Infect. Dis. 2015, 1, 544-554. [CrossRef] [PubMed]

46. Bush, K. The ABCD's of $\beta$-lactamase nomenclature. J. Infect. Chemother. 2013, 19, 549-559. [CrossRef]

47. Frère, J.M.; Galleni, M.; Bush, K.; Dideberg, O. Is it necessary to change the classification of \{beta\}-lactamases? J. Antimicrob. Chemother. 2005, 55, 1051-1053. [CrossRef]

48. Green, V.L.; Verma, A.; Owens, R.J.; Phillips, S.E.; Carr, S.B. Structure of New Delhi metallo- $\beta$-lactamase 1 (NDM-1). Acta Crystallogr. Sect. F Struct. Biol. Cryst. Commun. 2011, 67, 1160-1164. [CrossRef]

49. Tripathi, R.; Nair, N.N. Mechanism of Meropenem Hydrolysis by New Delhi Metallo $\beta$-Lactamase. Acs Catal. 2015, 5, 2577-2586. [CrossRef] 
50. Kim, Y.; Cunningham, M.A.; Mire, J.; Tesar, C.; Sacchettini, J.; Joachimiak, A. NDM-1, the ultimate promiscuous enzyme: Substrate recognition and catalytic mechanism. FASEB J. 2013, 27, 1917-1927. [CrossRef]

51. Zhu, K.; Lu, J.; Liang, Z.; Kong, X.; Ye, F.; Jin, L.; Geng, H.; Chen, Y.; Zheng, M.; Jiang, H.; et al. A quantum mechanics/molecular mechanics study on the hydrolysis mechanism of New Delhi metallo- $\beta$-lactamase-1. J. Comput. Aided Mol. Des. 2013, 27, 247-256. [CrossRef]

52. Doi, Y.; Hazen, T.H.; Boitano, M.; Tsai, Y.C.; Clark, T.A.; Korlach, J.; Rasko, D.A. Whole-genome assembly of Klebsiella pneumoniae coproducing NDM-1 and OXA-232 carbapenemases using single-molecule, real-time sequencing. Antimicrob. Agents Chemother. 2014, 58, 5947-5953. [CrossRef] [PubMed]

53. Yang, H.; Aitha, M.; Hetrick, A.M.; Richmond, T.K.; Tierney, D.L.; Crowder, M.W. Mechanistic and Spectroscopic Studies of Metallo- $\beta$-lactamase NDM-1. Biochemistry 2012, 51, 3839-3847. [CrossRef]

54. Jacquin, O.; Balbeur, D.; Damblon, C.; Marchot, P.; De Pauw, E.; Roberts, G.C.; Frère, J.M.; Matagne, A. Positively cooperative binding of zinc ions to Bacillus cereus $569 / \mathrm{H} / 9$ beta-lactamase II suggests that the binuclear enzyme is the only relevant form for catalysis. J. Mol. Biol. 2009, 392, 1278-1291. [CrossRef]

55. Page, M.I.; Badarau, A. The mechanisms of catalysis by metallo beta-lactamases. Bioinorg. Chem. Appl. 2008, $2008,576297$. [CrossRef]

56. Yang, H.; Aitha, M.; Marts, A.R.; Hetrick, A.; Bennett, B.; Crowder, M.W.; Tierney, D.L. Spectroscopic and mechanistic studies of heterodimetallic forms of metallo- $\beta$-lactamase NDM-1. J. Am. Chem. Soc. 2014, 136, 7273-7285. [CrossRef]

57. Pal, A.; Tripathi, A. An in silico approach for understanding the molecular evolution of clinically important metallo-betalactamases. Infect. Genet. Evol. 2013, 20, 39-47. [CrossRef]

58. Shi, M.; Xu, D.; Zeng, J. GPU accelerated quantum virtual screening: Application for the natural inhibitors of New Dehli metallo protein (NDM-1). Front. Chem. 2018, 6, 564-572. [CrossRef]

59. Krauss, M.; Gresh, N.; Antony, J. Binding and hydrolysis of ampicillin in the active site of a zinc lactamase. J. Phys. Chem. B 2003, 107, 1215-1229. [CrossRef]

60. Stewart, A.C.; Bethel, C.R.; VanPelt, J.; Bergstrom, A.; Cheng, Z.; Miller, C.G.; Williams, C.; Poth, R.; Morris, M.; Lahey, O. Clinical variants of New Delhi Metallo- $\beta$-Lactamase are evolving to overcome zinc scarcity. ACS Infect. Dis. 2017, 3, 927-940. [CrossRef] [PubMed]

61. Cheng, Z.; Thomas, P.W.; Ju, L.; Bergstrom, A.; Mason, K.; Clayton, D.; Miller, C.; Bethel, C.R.; VanPelt, J.; Tierney, D.L.; et al Evolution of New Delhi metallo- $\beta$-lactamase (NDM) in the clinic: Effects of NDM mutations on stability, zinc affinity, and mono-zinc activity. J. Biol. Chem. 2018, 293, 12606-12618. [CrossRef]

62. Mitra, S.D.; Sebastian, S.C.; Rekha, I.; Mudigonda, A.; Shome, B.R. Molecular detection of the new delhi metallo- $\beta$-lactamase clinical variant with double mutation-V88L and M154L in Escherichia coli isolates from South India. Gene Rep. 2020, 21, 100880. [CrossRef]

63. Raczynska, J.E.; Imiolczyk, B.; Komorowska, M.; Sliwiak, J.; Czyrko-Horczak, J.; Brzezinski, K.; Jaskolski, M. Flexible loops of New Delhi metallo- $\beta$-lactamase modulate its activity towards different substrates. Int. J. Biol. Macromol. 2020, 158, 104-115. [CrossRef] [PubMed]

64. Wu, W.; Feng, Y.; Tang, G.; Qiao, F.; McNally, A.; Zong, Z. NDM Metallo- $\beta$-Lactamases and their bacterial producers in health care settings. Clin. Microbiol. Rev. 2019, 32, e00115-18. [CrossRef] [PubMed]

65. Makena, A.; Brem, J.; Pfeffer, I.; Geffen, R.E.; Wilkins, S.E.; Tarhonskaya, H.; Flashman, E.; Phee, L.M.; Wareham, D.W.; Schofield, C.J. Biochemical characterization of New Delhi metallo- $\beta$-lactamase variants reveals differences in protein stability. J. Antimicrob. Chemother. 2015, 70, 463-469. [CrossRef] [PubMed]

66. Chen, J.; Chen, H.; Zhu, T.; Zhou, D.; Zhang, F.; Lao, X.; Zheng, H. Asp120Asn mutation impairs the catalytic activity of NDM-1 metallo- $\beta$-lactamase: Experimental and computational study. Phys. Chem. Chem. Phys. 2014, 16, 6709-6716. [CrossRef]

67. Ali, A.; Gupta, D.; Srivastava, G.; Sharma, A.; Khan, A.U. Molecular and computational approaches to understand resistance of New Delhi metallo $\beta$-lactamase variants (NDM-1, NDM-4, NDM-5, NDM-6, NDM-7)-producing strains against carbapenems. J. Biomol. Struct. Dyn. 2019, 37, 2061-2071. [CrossRef]

68. Ali, A.; Kumar, R.; Iquebal, M.A.; Jaiswal, S.; Kumar, D.; Khan, A.U. The role of conserved residues in the catalytic activity of NDM-1: An approach involving site directed mutagenesis and molecular dynamics. Phys. Chem. Chem. Phys. 2019, 21, 17821-17835. [CrossRef]

69. Bahr, G.; Vitor-Horen, L.; Bethel, C.R.; Bonomo, R.A.; González, L.J.; Vila, A.J. Clinical evolution of new delhi metallo- $\beta$-lactamase (ndm) optimizes resistance under zn(ii) deprivation. Antimicrob. Agents Chemother. 2017, 62, e01849-17. [CrossRef]

70. Patel, M.P.; Fryszczyn, B.G.; Palzkill, T. Characterization of the global stabilizing substitution A77V and its role in the evolution of CTX-M $\beta$-lactamases. Antimicrob. Agents Chemother. 2015, 59, 6741-6748. [CrossRef]

71. Tewari, R.; Mitra, S.D.; Ganaie, F.; Venugopal, N.; Das, S.; Shome, B.R. Prevalence of extended spectrum $\beta$-lactamase, AmpC $\beta$-lactamase and metallo $\beta$-lactamase mediated resistance in Escherichia coli from diagnostic and tertiary healthcare centers in south Bangalore, India. INT J. Med. Res. Health 2018, 6, 1308-1313. [CrossRef]

72. Ganta, S.R.; Perumal, S.; Pagadala, S.R.; Samuelsen, O.; Spencer, J.; Pratt, R.F.; Buynak, J.D. Approaches to the simultaneous inactivation of metallo- and serine-beta-lactamases. Bioorg. Med. Chem. Lett. 2009, 19, 1618-1622. [CrossRef] [PubMed]

73. Groundwater, P.W.; Xu, S.; Lai, F.; Váradi, L.; Tan, J.; Perry, J.D.; Hibbs, D.E. New Delhi metallo- $\beta$-lactamase-1: Structure, inhibitors and detection of producers. Future Med. Chem. 2016, 8, 993-1012. [CrossRef] 
74. Khan, A.U.; Rehman, M.T. Role of Non-Active-Site Residue Trp-93 in the Function and Stability of New Delhi Metallo- $\beta$-Lactamase 1. Antimicrob. Agents Chemother. 2015, 60, 356-360. [CrossRef]

75. Aitha, M.; Moller, A.J.; Sahu, I.D.; Horitani, M.; Tierney, D.L.; Crowder, M.W. Investigating the position of the hairpin loop in New Delhi metallo- $\beta$-lactamase, NDM-1, during catalysis and inhibitor binding. J. Inorg. Biochem. 2016, 156, 35-39. [CrossRef]

76. Khan, S.; Ali, A.; Khan, A.U. Structural and functional insight of New Delhi Metallo $\beta$-lactamase- 1 variants. Future Med. Chem. 2018, 10, 221-229. [CrossRef] [PubMed]

77. Liu, L.; Feng, Y.; McNally, A.; Zong, Z. blaNDM-21, a new variant of blaNDM in an Escherichia coli clinical isolate carrying blaCTX-M-55 and rmtB. J. Antimicrob. Chemother. 2018, 73, 2336-2339. [CrossRef] [PubMed]

78. Liu, Z.; Wang, Y.; Walsh, T.R.; Liu, D.; Shen, Z.; Zhang, R.; Yin, W.; Yao, H.; Li, J.; Shen, J. Plasmid-mediated novel blaNDM-17 gene encoding a carbapenemase with enhanced activity in a sequence type 48 Escherichia coli strain. Antimicrob. Agents Chemother. 2018, 61, e02233-16.

79. Hornsey, M.; Phee, L.; Wareham, D.W. A novel variant, NDM-5, of the New Delhi metallo- $\beta$-lactamase in a multidrug-resistant Escherichia coli ST648 isolate recovered from a patient in the United Kingdom. Antimicrob. Agents Chemother. 2011, 55, 5952-5954. [CrossRef]

80. Li, X.; Mu, X.; Zhang, P.; Zhao, D.; Ji, J.; Quan, J.; Zhu, Y.; Yu, Y. Detection and characterization of a clinical Escherichia coli ST3204 strain coproducing NDM-16 and MCR-1. Infect. Drug Resist. 2018, 11, 1189-1195. [CrossRef]

81. Liu, Z.; Piccirilli, A.; Liu, D.; Wang, Y.; Shen, J. Deciphering the Role of V881 Substitution in NDM-24 metallo- $\beta$-lactamase. Catalysts 2019, 9, 744. [CrossRef]

82. Liu, Z.; Li, J.; Wang, X.; Liu, D.; Ke, Y.; Wang, Y.; Shen, J. Novel variant of New Delhi Metallo- $\beta$-lactamase, NDM-20, in Escherichia coli. Front. Microbiol. 2018, 9, 248. [CrossRef] [PubMed]

83. Zou, D.; Huang, Y.; Zhao, X.; Liu, W.; Dong, D.; Li, H.; Wang, X.; Huang, S.; Wei, X.; Yan, X.; et al. A novel New Delhi Metallo- $\beta$-lactamase variant, NDM-14, isolated in a Chinese Hospital possesses increased enzymatic activity against carbapenems. Antimicrob. Agents Chemother. 2015, 59, 2450-2453. [CrossRef]

84. Nordmann, P.; Boulanger, A.E.; Poirel, L. NDM-4 Metallo- $\beta$-lactamase with increased carbapenemase activity from Escherichia coli. Antimicrob. Agents Chemother. 2012, 56, 2184-2186. [CrossRef] [PubMed]

85. Tada, T.; Miyoshi-Akiyama, T.; Dahal, R.K.; Sah, M.K.; Ohara, H.; Kirikae, T.; Pokhrel, B.M. NDM-8 metallo- $\beta$-lactamase in a multidrug-resistant Escherichia coli strain isolated in Nepal. Antimicrob. Agents Chemother. 2013, 57, 2394-2396. [CrossRef]

86. Göttig, S.; Hamprecht, A.G.; Christ, S.; Kempf, V.A.; Wichelhaus, T.A. Detection of NDM-7 in Germany, a new variant of the New Delhi metallo- $\beta$-lactamase with increased carbapenemase activity. J. Antimicrob. Chemother. 2013, 68, 1737-1740. [CrossRef] [PubMed]

87. Pal, L.R.; Moult, J. Genetic basis of Common Human Disease: Insight into the role of nonsynonymous SNPs from genome-wide association studies. J. Mol. Biol. 2015, 427, 2271-2289. [CrossRef]

88. Ali, A.; Azam, M.W.; Khan, A.U. Non-active site mutation (Q123A) in New Delhi metallo- $\beta$-lactamase (NDM-1) enhanced its enzyme activity. Int. J. Biol. Macromol. 2018, 112, 1272-1277. [CrossRef]

89. Mancini, S.; Keller, P.M.; Greiner, M.; Bruderer, V.; Imkamp, F. Detection of NDM-19, a novel variant of the New Delhi metallo- $\beta$ lactamase with increased carbapenemase activity under zinc-limited conditions, in Switzerland. Diagn. Microbiol. Infect. Dis. 2019, 95, 114851. [CrossRef]

90. Lascols, C.; Hackel, M.; Marshall, S.H.; Hujer, A.M.; Bouchillon, S.; Badal, R.; Hoban, D.; Bonomo, R.A. Increasing prevalence and dissemination of NDM-1 metallo- $\beta$-lactamase in India: Data from the SMART study (2009). J. Antimicrob. Chemother. 2011, 66, 1992-1997. [CrossRef]

91. Bonnin, R.A.; Poirel, L.; Naas, T.; Pirs, M.; Seme, K.; Schrenzel, J.; Nordmann, P. Dissemination of New Delhi metallo- $\beta$-lactamase1-producing Acinetobacter baumannii in Europe. Clin. Microbiol. Infect. 2012, 18, E362-E365. [CrossRef]

92. Rahman, M.; Mukhopadhyay, C.; Rai, R.P.; Singh, S.; Gupta, S.; Singh, A.; Pathak, A.; Prasad, K.N. Novel variant NDM-11 and other NDM-1 variants in multidrug-resistant Escherichia coli from South India. J. Glob. Antimicrob. Resist. 2018, 14, 154-157. [CrossRef]

93. Khan, A.U.; Nordmann, P. NDM-1-producing Enterobacter cloacae and Klebsiella pneumoniae from diabetic foot ulcers in India. J. Med. Microbiol. 2012, 61, 454-456. [CrossRef]

94. Khan, A.U.; Maryam, L.; Zarrilli, R. Structure, genetics and worldwide spread of New Delhi Metallo- $\beta$-lactamase (NDM): A threat to public health. BMC Microbiol. 2017, 17, 101. [CrossRef] [PubMed]

95. Espinal, P.; Fugazza, G.; López, Y.; Kasma, M.; Lerman, Y.; Malhotra-Kumar, S.; Goossens, H.; Carmeli, Y.; Vila, J. Dissemination of an NDM-2-producing Acinetobacter baumannii clone in an Israeli rehabilitation center. Antimicrob. Agents Chemother. 2011, 55, 5396-5398. [CrossRef]

96. Cantón, R.; Akóva, M.; Carmeli, Y.; Giske, C.G.; Glupczynski, Y.; Gniadkowski, M.; Livermore, D.M.; Miriagou, V.; Naas, T.; Rossolini, G.M.; et al. Rapid evolution and spread of carbapenemases among Enterobacteriaceae in Europe. Clin. Microbiol. Infect. 2012, 18, 413-431. [CrossRef] [PubMed]

97. Eu, W. Updated ECDC Risk Assessment on the Spread of New Delhi Metallo- $\beta$-lactamase and Its Variants within Europe; European Centre for Disease Prevention and Control: Stockholm, Sweden, 2011.

98. Coppo, E.; Del Bono, V.; Ventura, F.; Camera, M.; Orengo, G.; Viscoli, C.; Marchese, A. Identification of a New Delhi metallo- $\beta$ lactamase-4 (NDM-4)-producing Escherichia coli in Italy. BMC Microbiol. 2014, 14, 148. [CrossRef] 
99. Sassi, A.; Loucif, L.; Gupta, S.K.; Dekhil, M.; Chettibi, H.; Rolain, J.M. NDM-5 carbapenemase-encoding gene in multidrugresistant clinical isolates of Escherichia coli from Algeria. Antimicrob. Agents Chemother. 2014, 58, 5606-5608. [CrossRef] [PubMed]

100. Poirel, L.; Lagrutta, E.; Taylor, P.; Pham, J.; Nordmann, P. Emergence of metallo- $\beta$-lactamase NDM-1-producing multidrugresistant Escherichia coli in Australia. Antimicrob. Agents Chemother. 2010, 54, 4914-4916. [CrossRef]

101. Tondi, D.; Venturelli, A.; Bonnet, R.; Pozzi, C.; Shoichet, B.K.; Costi, M.P. Targeting class A and C serine $\beta$-lactamases with a broad-spectrum boronic acid derivative. J. Med. Chem. 2014, 57, 5449-5458. [CrossRef]

102. Focco, V.; Bonomo, R.A. Exploring additional dimensions of complexity in inhibitor design for serine $\beta$-lactamases: Mechanistic and intra- and inter-molecular chemistry approaches. Front. Microbiol. 2018, 9, 622-632.

103. Liénard, B.M.; Garau, G.; Horsfall, L.; Karsisiotis, A.I.; Damblon, C.; Lassaux, P.; Papamicael, C.; Roberts, G.C.; Galleni, M.; Dideberg, O.; et al. Structural basis for the broad-spectrum inhibition of Metallo- $\beta$-lactamases by thiols. Org. Biomol. Chem. 2008, 6, 2282-2294. [CrossRef]

104. King, A.M.; Reid-Yu, S.A.; Wang, W.; King, D.T.; De Pascale, G.; Strynadka, N.C.; Walsh, T.R.; Coombes, B.K.; Wright, G.D. Aspergillomarasmine A overcomes metallo- $\beta$-lactamase antibiotic resistance. Nature 2014, 510, 503-506. [CrossRef] [PubMed]

105. Yoshizumi, A.; Ishii, Y.; Livermore, D.M.; Woodford, N.; Kimura, S.; Saga, T.; Harada, S.; Yamaguchi, K.; Tateda, K. Efficacies of calcium-EDTA in combination with imipenem in a murine model of sepsis caused by Escherichia coli with NDM-1 $\beta$-lactamase. J. Infect. Chemother. 2013, 19, 992-995. [CrossRef] [PubMed]

106. Drawz, S.M.; Bonomo, R.A. Three decades of $\beta$-lactamase inhibitors. Clin. Microbiol. Rev. 2010, 23, 160-201. [CrossRef]

107. Buynak, J.D. $\beta$-Lactamase inhibitors: A review of the patent literature (2010-2013). Expert Opin Ther Pat. 2013, 23, 1469-1481. [CrossRef]

108. Livermore, D.M.; Mushtaq, S.; Morinaka, A.; Ida, T.; Maebashi, K.; Hope, R. Activity of carbapenems with ME1071 (disodium 2,3-diethylmaleate) against Enterobacteriaceae and Acinetobacter spp. with carbapenemases, including NDM enzymes. J. Antimicrob. Chemother. 2013, 68, 153-158. [CrossRef]

109. Niskanen, L.; Hedner, T.; Hansson, L.; Lanke, J.; Niklason, A.C. Study Group. Reduced cardiovascular morbidity and mortality in hypertensive diabetic patients on first-line therapy with an ACE inhibitor compared with a diuretic/beta-blocker-based treatment regimen: A subanalysis of the Captopril Prevention Project. Diabetes Care. 2001, 24, 2091-2096. [CrossRef]

110. Yusof, Y.; Tan, D.T.C.; Arjomandi, O.K.; Schenk, G.; McGeary, R.P. Captopril analogues as metallo- $\beta$-lactamase inhibitors. Bioorg. Med. Chem. Lett. 2016, 26, 1589-1593. [CrossRef] [PubMed]

111. Brem, J.; Berkel, S.S.; Zollman, D.; Lee, S.Y.; Gileadi, O.; McHugh, P.J.; Walsh, T.R.; McDonough, M.A. Schofield CJ. Structural Basis of Metallo- $\beta$-Lactamase Inhibition by Captopril Stereoisomers. Antimicrob. Agents Chemother. 2015, 60, 142-150. [CrossRef]

112. Li, N.; Xu, Y.; Xia, Q.; Bai, C.; Wang, T.; Wang, L.; He, D.; Xie, N.; Li, L.; Wang, J.; et al. Simplified captopril analogues as NDM-1 inhibitors. Bioorg. Med. Chem. Lett. 2014, 24, 386-389. [CrossRef]

113. García-Sáez, I.; Mercuri, P.S.; Papamicael, C.; Kahn, R.; Frère, J.M.; Galleni, M.; Rossolini, G.M.; Dideberg, O. Three-dimensional structure of FEZ-1, a monomeric subclass B3 metallo-beta-lactamase from Fluoribacter gormanii, in native form and in complex with D-captopril. J. Mol. Biol. 2003, 325, 651-660. [CrossRef]

114. Skagseth, S.; Akhter, S.; Paulsen, M.H.; Muhammad, Z.; Lauksund, S.; Samuelsen, Ø.; Leiros, H.S.; Bayer, A. Metallo- $\beta$-lactamase inhibitors by bioisosteric replacement: Preparation, activity and binding. Eur. J. Med. Chem. 2017, 135, 159-173. [CrossRef]

115. Yamada, K.; Yanagihara, K.; Kaku, N.; Harada, Y.; Migiyama, Y.; Nagaoka, K.; Morinaga, Y.; Nakamura, S.; Imamura, Y.; Miyazaki, T.; et al. In vivo efficacy of biapenem with ME1071, a novel metallo- $\beta$-lactamase (MBL) Inhibitor, in a murine model mimicking ventilator-associated pseumonia caused by MBL-producing Pseudomonas aeruginosa. Int. J. Antimicrob. Agents 2013, 42, 238-243. [CrossRef]

116. Klingler, F.M.; Wichelhaus, T.A.; Frank, D.; Cuesta-Bernal, J.; El-Delik, J.; Müller, H.F.; Sjuts, H.; Göttig, S.; Koenigs, A.; Pos, K.M.; et al. Approved drugs Containing thiols as inhibitors of Metallo- $\beta$-lactamases: Strategy to combat multidrug-resistant bacteria. J. Med. Chem. 2015, 58, 3626-3630. [CrossRef]

117. Tehrani, K.H.M.E.; Martin, N.I. Thiol-containing Metallo- $\beta$-Lactamase inhibitors resensitize resistant gram-negative bacteria to meropenem. ACS Infect. Dis. 2017, 3, 711-717. [CrossRef]

118. Hinchliffe, P.; González, M.M.; Mojica, M.F.; González, J.M.; Castillo, V.; Saiz, C.; Kosmopoulou, M.; Tooke, C.L.; Llarrull, L.I.; Mahler, G.; et al. Cross-class Metallo- $\beta$-lactamase inhibition by bisthiazolidines reveals multiple binding modes. Proc. Natl. Acad. Sci. USA 2016, 113, E3745-E3754. [CrossRef] [PubMed]

119. Cain, R.; Brem, J.; Zollman, D.; McDonough, M.A.; Johnson, R.M.; Spencer, J.; Makena, A.; Abboud, M.I.; Cahill, S.; Lee, S.Y.; et al. In silico fragment-based design identifies subfamily B1 Metallo- $\beta$-lactamase inhibitors. J. Med. Chem. 2018, 61, 1255-1260. [CrossRef]

120. Bauer, R. Binding of D- and L-captopril inhibitors to metallo-beta-lactamase studied by polarizable molecular mechanics and quantum mechanics. J. Comput. Chem. 2002, 23, 1281-1296.

121. Antony, J.; Piquemal, J.P.; Gresh, N. Complexes of thiomandelate and captopril mercaptocarboxylate inhibitors to metallo-betalactamase by polarizable molecular mechanics. validation on model binding sites by quantum chemistry. J. Comput. Chem. 2005, 26, 1131-1147. [CrossRef] [PubMed] 
122. Hinchliffe, P.; Moreno, D.M.; Rossi, M.A.; Mojica, M.F.; Martinez, V.; Villamil, V.; Spellberg, B.; Drusano, G.L.; Banchio, C.; Mahler, G.; et al. 2-Mercaptomethyl thiazolidines (MMTZS) inhibit all metallo- $\beta$-lactamase classes by maintaining a conserved binding mode. ACS Infect. Dis. 2021, 7, 2697-2706. [CrossRef]

123. Zervosen, A.; Sauvage, E.; Frère, J.M.; Charlier, P.; Luxen, A. Development of new drugs for an old target: The penicillin binding proteins. Molecules 2012, 17, 12478-12505. [CrossRef] [PubMed]

124. Zervosen, A.; Lu, W.P.; Chen, Z.; White, R.E.; Demuth, T.P.; Frère, J.M. Interactions between penicillin-binding proteins (PBPs) and two novel classes of PBP inhibitors, arylalkylidene rhodanines and arylalkylidene iminothiazolidin-4-ones. Antimicrob. Agents Chemother. 2004, 48, 961-969. [CrossRef] [PubMed]

125. Brem, J.; van Berkel, S.S.; Aik, W.; Rydzik, A.M.; Avison, M.B.; Pettinati, I.; Umland, K.D.; Kawamura, A.; Spencer, J.; Claridge, T.D.; et al. Rhodanine hydrolysis leads to potent thioenolate mediated metallo- $\beta$-lactamase inhibition. Nat. Chem. 2014, 6, 1084-1090. [CrossRef] [PubMed]

126. Xiang, Y.; Chen, C.; Wang, W.M.; Xu, L.W.; Yang, K.W.; Oelschlaeger, P.; He, Y. Rhodanine as a potent scaffold for the development of broad-spectrum Metallo- $\beta$-lactamase inhibitors. ACS Med. Chem Lett. 2018, 9, 359-364. [CrossRef]

127. Falconer, S.B.; Wang, W.; Gehrke, S.S.; Cuneo, J.D.; Britten, J.F.; Wright, G.D.; Brown, E.D. Metal-induced isomerization yields an intracellular chelator that disrupts bacterial iron homeostasis. Chem. Biol. 2014, 21, 136-145. [CrossRef]

128. Falconer, S.B.; Reid-Yu, S.A.; King, A.M.; Gehrke, S.S.; Wang, W.; Britten, J.F.; Coombes, B.K.; Wright, G.D.; Brown, E.D. Zinc chelation by a small-molecule adjuvant potentiates meropenem activity in vivo against NDM-1-producing klebsiella pneumoniae. ACS Infect. Dis. 2015, 1, 533-543. [CrossRef]

129. Ai, X.; Liu, H.; Lu, C.; Liang, C.; Sun, Y.; Chen, S.; Sun, B.; Li, Y.; Liu, Y.; Zhang, Q.; et al. Phenytoin silver: A new nanocompound for nromoting dermal wound healing via comprehensive pharmacological action. Theranostics 2017, 7, 425-435. [CrossRef]

130. Pandeya, S.N.; Smitha, S.; Jyoti, M.; Sridhar, S.K. Biological activities of isatin and its derivatives. Acta Pharm. 2005, 55, 27-46.

131. Song, G.; Wang, W.; Li, Z.; Wang, Y.; Wang, J. First identification of isatin- $\beta$-thiosemicarbazones as novel inhibitors of New Delhi Metallo- $\beta$-lactamase-1: Chemical synthesis, biological evaluation and molecular simulation. Chin. Chem. Lett. 2018, 29, 899-902. [CrossRef]

132. Zhang, X.M.; Guo, H.; Li, Z.S.; Song, F.H.; Wang, W.M.; Dai, H.Q.; Zhang, L.X.; Wang, J.G. Synthesis and evaluation of isatin- $\beta$ thiosemicarbazones as novel agents against antibiotic-resistant Gram-positive bacterial species. Eur. J. Med. Chem. 2015, 101, 419-430. [CrossRef]

133. Chen, A.Y.; Thomas, P.W.; Stewart, A.C.; Bergstrom, A.; Cheng, Z.; Miller, C.; Bethel, C.R.; Marshall, S.H.; Credille, C.V.; Riley, C.L.; et al. Dipicolinic acid derivatives as inhibitors of New Delhi Metallo- $\beta$-lactamase-1. J. Med. Chem. 2017, 60, 7267-7283. [CrossRef]

134. Hinchliffe, P.; Tanner, C.A.; Krismanich, A.P.; Labbé, G.; Goodfellow, V.J.; Marrone, L.; Desoky, A.Y.; Calvopiña, K.; Whittle, E.E.; Zeng, F.; et al. Structural and kinetic studies of the potent inhibition of metallo- $\beta$-lactamases by 6-phosphonomethylpyridine-2carboxylates. Biochemistry 2018, 57, 1880-1892. [CrossRef] [PubMed]

135. Mavrova, A.; Wesselinova, D.; Tsenov, Y.A.; Denkova, P. Synthesis, cytotoxicity and effects of some 1,2,4-triazole and 1,3,4thiadiazole derivatives on immunocompetent cells. Eur. J. Med. Chem. 2009, 44, 63-69. [CrossRef]

136. Kwapien, K.; Damergi, M.; Nader, S.; El Khoury, L.; Hobaika, Z.; Maroun, R.G.; Piquemal, J.P.; Gavara, L.; Berthomieu, D.; Hernandez, J.F.; et al. Calibration of 1,2,4-triazole-3-thione, an original Zn-binding group of metallo- $\beta$-lactamase inhibitors. validation of a polarizable MM/MD potential by quantum chemistry. J. Phys. Chem. B 2017, 121, 6295-6312. [CrossRef]

137. Sevaille, L.; Gavara, L.; Bebrone, C.; De Luca, F.; Nauton, L.; Achard, M.; Mercuri, P.; Tanfoni, S.; Borgianni, L.; Guyon, C.; et al 1,2,4-Triazole-3-thione compounds as inhibitors of dizinc metallo- $\beta$-lactamases. Chemmedchem 2017, 12, 972-985. [CrossRef] [PubMed]

138. Gavara, L.; Sevaille, L.; De Luca, F.; Mercuri, P.; Bebrone, C.; Feller, G.; Legru, A.; Cerboni, G.; Tanfoni, S.; Baud, D.; et al. 4-Amino-1,2,4-triazole-3-thione-derived Schiff bases as metallo- $\beta$-lactamase inhibitors. Eur. J. Med. Chem. 2020, $208,112720$. [CrossRef]

139. Fu, H.; Fang, H.; Sun, J.; Wang, H.; Liu, A.; Sun, J.; Wu, Z. Boronic acid-based enzyme inhibitors: A review of recent progress. Curr. Med. Chem. 2014, 21, 3271-3280. [CrossRef] [PubMed]

140. Brem, J.; Cain, R.; Cahill, S.; McDonough, M.A.; Clifton, I.J.; Jiménez-Castellanos, J.C.; Avison, M.B.; Spencer, J.; Fishwick, C.W.; Schofield, C.J. Structural basis of metallo- $\beta$-lactamase, serine- $\beta$-lactamase and penicillin-binding protein inhibition by cyclic boronates. Nat. Commun. 2016, 7, 12406. [CrossRef]

141. Hecker, S.J.; Reddy, K.R.; Lomovskaya, O.; Griffith, D.C.; Rubio-Aparicio, D.; Nelson, K.; Tsivkovski, R.; Sun, D.; Sabet, M.; Tarazi, Z.; et al. Discovery of cyclic boronic acid Qpx7728, an ultra-broad-spectrum inhibitor of serine and metallo beta-lactamases. J. Med. Chem. 2020, 63, 7491-7507. [CrossRef] [PubMed]

142. Santucci, M.; Spyrakis, F.; Cross, S.; Quotadamo, A.; Farina, D.; Tondi, D.; De Luca, F.; Docquier, J.D.; Prieto, A.I.; Ibacache, C.; et al. Computational and biological profile of boronic acids for the detection of bacterial serine- and metallo- $\beta$-lactamases. Sci. Rep. 2017, 7, 17716. [CrossRef]

143. Krajnc, A.; Brem, J.; Hinchliffe, P.; Calvopiña, K.; Panduwawala, T.D.; Lang, P.A.; Kamps, J.J.A.G.; Tyrrell, J.M.; Widlake, E.; Saward, B.G.; et al. Bicyclic boronate VNRX-5133 inhibits metallo- and serine- $\beta$-lactamases. J. Med. Chem. 2019, 62, 8544-8556. [CrossRef] [PubMed] 
144. Aaseth, J.; Skaug, M.A.; Cao, Y.; Andersen, O. Chelation in metal intoxication-principles and paradigms. J. Trace. Elem. Med. Biol. 2015, 31, 260-266. [CrossRef] [PubMed]

145. Ma, J.; McLeod, S.; MacCormack, K.; Sriram, S.; Gao, N.; Breeze, A.L.; Hu, J. Real-time monitoring of New Delhi metallo$\beta$-lactamase activity in living bacterial cells by 1HNMR spectroscopy. Angew. Chem. Int. Ed. Engl. 2014, 53, $2130-2133$. [CrossRef]

146. Somboro, A.M.; Tiwari, D.; Bester, L.A.; Parboosing, R.; Chonco, L.; Kruger, H.G.; Arvidsson, P.I.; Govender, T.; Naicker, T.; Essack, S.Y. NOTA: A potent metallo- $\beta$-lactamase inhibitor. J. Antimicrob. Chemother. 2015, 70, 1594-1956. [CrossRef] [PubMed]

147. Andreini, C.; Bertini, I. A bioinformatics view of zinc enzymes. J. Inorg. Biochem. 2012, 111, 150-156. [CrossRef] [PubMed]

148. Arai, K.; Ashikawa, N.; Nakakita, Y.; Matsuura, A.; Munekata, M. Aspergillomarasmine A and B, potent microbial inhibitors of endothelin-converting enzyme. Biosci. Biotech. Bioch. 2014, 57, 1944-1945. [CrossRef]

149. Mikami, Y.; Suzuki, T. Novel microbial inhibitors of angiotensin-converting enzyme, aspergillomarasmines A and B. J. Agric. Chem. Soc. Jpn. 1983, 47, 2693-2695.

150. Koteva, K.; King, A.M.; Caprett, A.; Wright, G.D. Total synthesis and activity of the metallo- $\beta$-lactamase inhibitor Aspergillomarasmine A. Angew. Chem. 2016, 55, 2210-2212. [CrossRef]

151. Zhang, J.; Wang, S.; Wei, Q.; Guo, Q.; Bai, Y.; Yang, S.; Song, F.; Zhang, L.; Lei, X. Synthesis and biological evaluation of Aspergillomarasmine a derivatives as novel NDM-1 inhibitor to overcome antibiotics resistance. Bioorg. Med. Chem. 2017, 25, 5133-5141. [CrossRef]

152. Thomas, P.W.; Spicer, T.; Cammarata, M.; Brodbelt, J.S.; Hodder, P.; Fast, W. An altered zinc-binding site confers resistance to a covalent inactivator of New Delhi metallo-beta-lactamase-1 (NDM-1) discovered by high-throughput screening. Bioorg. Med. Chem. 2013, 21, 3138-3146. [CrossRef]

153. Parnham, M.J.; Sies, H. The early research and development of ebselen. Biochem. Pharmacol. 2013, 86, 1248-1253. [CrossRef]

154. Chiou, J.; Wan, S.; Chan, K.F.; So, P.K.; He, D.; Chan, E.W.; Chan, T.H.; Wong, K.Y.; Tao, J.; Chen, S. Ebselen as a potent covalent inhibitor of New Delhi metallo- $\beta$-lactamase (NDM-1). Chem. Commun. 2015, 51, 9543-9546. [CrossRef] [PubMed]

155. Jin, W.; Xu, C.; Cheng, Q.; Qi, X.; Gao, W.; Zheng, Z.; Chan, E.W.C.; Leung, Y.; Chan, T.; Wong, K.; et al. Investigation of synergistic antimicrobial effects of the drug combinations of meropenem and 1,2-benzisoselenazol-3(2H)-one derivatives on carbapenem-resistant Enterobacteriaceae producing NDM-1. Eur. J. Med. Chem. 2018, 155, 285-302. [CrossRef]

156. Su, J.; Liu, J.; Chen, C.; Zhang, Y.; Yang, K. Ebsulfur as a potent scaffold for inhibition and labelling of New Delhi metallo- $\beta$ lactamase-1 in vitro and in vivo. Bioorg. Chem. 2019, 84, 192-201. [CrossRef]

157. Darabedian, N.; Chen, T.C.; Molina, H.; Pratt, M.R.; Schönthal, A.H. Bioorthogonal profiling of a cancer cell proteome identifies a large set of 3-bromopyruvate targets beyond glycolysis. ACS Chem. Biol. 2018, 13, 3054-3058. [CrossRef]

158. Kang, P.; Su, J.; Sun, L.; Gao, H.; Yang, K. 3-Bromopyruvate as a potent covalently reversible inhibitor of New Delhi metallo- $\beta$ lactamase-1 (NDM-1). Eur. J. Pharm. Sci. 2020, 142, 105161. [CrossRef] [PubMed]

159. Thomas, P.W.; Cammarata, M.; Brodbelt, J.S.; Fast, W. Covalent inhibition of New Delhi metallo- $\beta$-lactamase-1 (NDM-1) by cefaclor. Chembiochem 2014, 15, 2541-2548. [CrossRef]

160. Christopeit, T.; Albert, A.; Leiros, H.S. Discovery of a novel covalent non- $\beta$-lactam inhibitor of the metallo- $\beta$-lactamase NDM-1. Bioorg. Med. Chem. 2016, 24, 2947-2953. [CrossRef] [PubMed]

161. Thomas, P.W.; Cammarata, M.; Brodbelt, J.S.; Monzingo, A.F.; Pratt, R.F.; Fast, W. A lysine-targeted affinity label for serine- $\beta$ lactamase also covalently modifies New Delhi Metallo- $\beta$-lactamase-1 (NDM-1). Biochemistry 2019, 58, 2834-2843. [CrossRef]

162. Sully, E.K.; Geller, B.L.; Li, L.; Moody, C.M.; Bailey, S.M.; Moore, A.L.; Wong, M.; Nordmann, P.; Daly, S.M.; Sturge, C.R.; et al Peptide-conjugated phosphorodiamidate morpholino oligomer (PPMO) restores carbapenem susceptibility to NDM-1-positive pathogens in vitro and in vivo. J. Antimicrob. Chemother. 2017, 72, 782-790.

163. Chandar, B.; Poovitha, S.; Ilango, K.; MohanKumar, R.; Parani, M. Inhibition of New Delhi Metallo- $\beta$-Lactamase 1 (NDM-1) producing Escherichia coli IR-6 by selected plant extracts and their synergistic actions with antibiotics. Front. Microbiol. 2017, 8, 1580. [CrossRef] [PubMed]

164. Everett, M.; Sprynski, N.; Coelho, A.; Castandet, J.; Lemonnier, M. Discovery of a novel metallo-ß3-lactamase inhibitor, which can potentiate meropenem activity against carbapenem-resistant enterobacteriaceae. Antimicrob. Agents Chemother. 2018, 62, e00074-18. [CrossRef]

165. Liu, S.; Zhang, J.; Zhou, Y.; Hu, N.; Li, J.; Wang, Y.; Niu, X.; Deng, X.; Wang, J. Pterostilbene restores carbapenem susceptibility in New Delhi metallo- $\beta$-lactamase-producing isolates by inhibiting the activity of New Delhi metallo- $\beta$-lactamases. Br. J. Pharmacol. 2019, 176, 4548-4557. [CrossRef] [PubMed]

166. Liu, S.; Zhou, Y.; Niu, X.; Wang, T.; Li, J.; Liu, Z.; Wang, J.; Tang, S.; Wang, Y.; Deng, X. Magnolol restores the activity of meropenem against NDM-1-producing Escherichia coli by inhibiting the activity of metallo-beta-lactamase. Cell Death Discov. 2018, 4, 28. [CrossRef] [PubMed]

167. Kazi, M.I.; Perry, B.W.; Card, D.C.; Schargel, R.D.; Ali, H.B.; Obuekwe, V.C.; Sapkota, M.; Kang, K.N.; Pellegrino, M.W.; Greenberg, D.E.; et al. Discovery and characterization of New Delhi metallo- $\beta$-lactamase-1 inhibitor peptides that potentiate meropenem-dependent killing of carbapenemase-producing Enterobacteriaceae. J. Antimicrob. Chemother. 2020, 75, $2843-2851$. [CrossRef] 